\title{
THE LAST MAXIMUM ICE EXTENT AND SUBSEQUENT DEGLACIATION OF THE PYRENEES: AN OVERVIEW OF RECENT RESEARCH
}

\author{
M. DELMAS
}

\begin{abstract}
Université de Perpignan-Via Domitia, UMR 7194 CNRS, Histoire Naturelle de
\end{abstract} l’Homme Préhistorique, 52 avenue Paul Alduy 66860 Perpignan, France.

\begin{abstract}
This paper reviews data currently available on the glacial fluctuations that occurred in the Pyrenees between the Würmian Maximum Ice Extent (MIE) and the beginning of the Holocene. It puts the studies published since the end of the 19th century in a historical perspective and focuses on how the methods of investigation used by successive generations of authors led them to paleogeographic and chronologic conclusions that for a time were antagonistic and later became complementary. The inventory and mapping of the ice-marginal deposits has allowed several glacial stades to be identified, and the successive ice boundaries to be outlined. Meanwhile, the weathering grade of moraines and glaciofluvial deposits has allowed Würmian glacial deposits to be distinguished from pre-Würmian ones, and has thus allowed the Würmian Maximum Ice Extent (MIE) -i.e. the starting point of the last deglaciation- to be clearly located. During the $1980 s,{ }^{14} \mathrm{C}$ dating of glaciolacustrine sequences began to indirectly document the timing of the glacial stades responsible for the adjacent frontal or lateral moraines. Over the last decade, in situ-produced cosmogenic nuclides $\left({ }^{10} \mathrm{Be}\right.$ and $\left.{ }^{36} \mathrm{Cl}\right)$ have been documenting the deglaciation process more directly because the data are obtained from glacial landforms or deposits such as boulders embedded in frontal or lateral moraines, or icepolished rock surfaces. On that basis, it is now accepted that (i) the Würmian MIE occurred in the Pyrenees during MIS 4 and not the Global LGM; and that (ii) a major glacial readvance took place during the Global LGM. This ice readvance reached a position close to the MIS 4 icefield boundary in the Eastern part of the range, but apparently not in the west. (iii) Soon after the Global LGM, the Pyrenean ice margin went into major and rapid recession. Even before the beginning of the Lateglacial, the main trunk glaciers had already retreated to the upper parts of the valleys. (iv) The paleogeography of the Pyrenean icefield during the Last Glacial-Interglacial Transition (LGIT) is still partially unknown but all available data indicate that glaciers during the Oldest Dryas (GS-2a) were

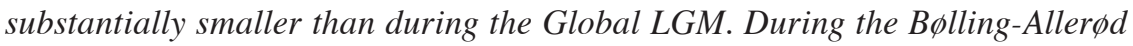
interstadial, the Pyrenean ice margins retreated substantially, and glaciers
\end{abstract}


locally vanished definitively. The Younger Dryas cooling event generated either a short readvance of existing cirque glaciers or the development of rock glaciers.

\section{La última máxima extensión del hielo y posterior deglaciación de los Pirineos: revision de la investigación reciente}

RESUMEN. Este trabajo revisa los datos disponibles sobre las fluctuaciones glaciares que ocurrieron en los Pirineos entre la máxima extension wurmiense del hielo y el comienzo del Holoceno. Sitúa los estudios publicados desde finales del siglo XIX en una perspectiva histórica y analiza cómo los métodos de investigación utilizados por sucesivas generaciones de autores les condujeron a conclusions paleogeográficas y cronológicas que fueron antagonistas durante un tiempo y más tarde pasaron a ser complementarias. El inventario y cartografía de los depósitos glaciares marginales ha permitido identificar diferentes estadios glaciares y delimitar la extension del hielo. Además, el grado de meteorización de las morrenas y de los depósitos glaciofluviales ha permitido distinguir los depósitos glaciares wurmienses de los pre-wurmienses, así como localizar claramente la máxima extension de los glaciares wurmienses, es decir, el punto de partida de la última deglaciación. Durante los años 80 del siglo XX la datación mediante ${ }^{14} \mathrm{C}$ de secuencias glaciolacustres documentó indirectamente el momento de los estadios glaciares responsables de las morrenas frontales o laterales adyacentes. Durante la última década, la datación mediante cosmogénicos $\left({ }^{10} \mathrm{Be} y{ }^{36} \mathrm{Cl}\right)$ ha documentado los procesos de deglaciación de manera más directa porque los datos se han obtenidos de formas glaciares o de depósitos, tales como grandes bloques integrados en morenas frontales o laterales o superficies rocosas pulidas. Sobre esta base, se acepta ahora que (i) la máxima extensión del hielo wurmiense ocurrió en los Pirineos durante el MIS 4 y no durante el Último Máximo Global; y (ii) que un gran reavance glaciar ocurrió durante el Último Máximo Global. Este reavance del hielo ocupó una posición próxima al límite del hielo durante el MIS 4, aunque aparentemente no en la parte más occidental. (iii) Después del Último Máximo Global los glaciares pirenaicos entraron en una gran y rápida recesión. Incluso antes del comienzo del Tardiglaciar las principales lenguas glaciares ya se habian retirado hacia las partes superiores de los valles. (iv) La paleogeografía de los campos de hielo pirenaicos durante la última transición glacial-interglacial se desconoce todavía parcialmente, aunque todos los datos disponibles indican que durante el Oldest Dryas $(G S-2 a)$ los glaciares fueron sustancialmente menores que durante el Último Máximo Global. Durante el interestadial Bølling-Aller $\phi d$ los glaciares pirenaicos se retiraron notablemente, y localmente desaparecieron de manera definitiva. El evento frío del Younger Dryas dio lugar a un corto reavance de los glaciares de circo o al desarrollo de glaciares rocosos.

Key words: Würmian icefield boundary, Global LGM, Last Glacial-Interglacial Termination, cosmogenic nuclides, radiocarbon dating, Pyrenees. 
Palabras clave: límites del hielo wurmiense, Último Máximo Global, Último final Glacial-Interglacial, cosmogénicos, datación por radiocarbono, Pirineos.

Received 31 January 2015

Accepted 10 April 2015

* Corresponding author: Université de Perpignan-Via Domitia, UMR 7194 CNRS, Histoire Naturelle de l'Homme Préhistorique, 52 avenue Paul Alduy 66860 Perpignan, France. E-mail: magali.delmas@univ-perp.fr

\section{Introduction}

A growing body of research has been focusing on the glacial extent and chronology of Pyrenean Pleistocene glaciations. The modalities of the last deglaciation, however, are still poorly known, likely because studies published until now have mainly dealt with terminal moraine systems and much less with till deposits located farther up-valley and in the cirques. This paper reviews current knowledge of glacial fluctuations in the Pyrenees between the last Maximum Ice Extent (MIE) and the beginning of the Holocene. It also provides a synthesis of the glacial extent and chronology of the Würmian MIE because these data set the starting point of the last deglaciation process. The Global LGM is defined as the time of the most recent and largest globally integrated ice mass. This latest peak volume of ice on Earth prevailed between $23 \mathrm{ka}$ cal. BP and $19 \mathrm{ka}$ cal. BP (MARGO project Members, 2009) and coincided with extremely low and stable sea levels $(-135 \mathrm{~m})$. The Last Glacial-Interglacial Transition (LGIT) refers to the time interval between the Global LGM and the beginning of the Holocene (Wohlfarth, 1996; Hoek, 2009; Denton et al., 2010). This time interval was characterized by intense, fast and abrupt climatic changes. The LGIT-related climatic changes were initially detected from North European pollen records (Oldest Dryas-, Bølling-, Older Dryas-, Allerød-, Younger Dryas- and Preboreal-Chronozones, Mangerud et al., 1974), but has now been well constrained and well dated with the help of isotopic data from the Greenland ice cores, proposing a new terminology and chronology that is widely accepted (Rasmussen et al., 2006; Lowe et al., 2008; Svensson et al., 2008; Blockley et al., 2012; Rasmussen et al., 2014).

In the Pyrenees, the time range likely to cover the deglaciation process is a priori longer than that recorded on a global scale (i.e., during the strict duration of the LGIT) because all the geochronological data acquired from Pyrenean terminal moraines indicate that the last Pyrenean MIE occurred earlier than the Global LGM and was, instead, contemporaneous of the MIS 4 (review in Calvet et al., 2011; García-Ruiz et al., 2013).

What happened in the Pyrenees between MIS 4 and the beginning of the Holocene? When did the outlet glaciers retreat back from the Würmian MIE terminal moraines and become confined to the valley headwaters? Was it during MIS 3, or only after the Global LGM? Where were Pyrenean glaciers positioned during the Global LGM? Were they far apart, or, instead, quite close to the MIS 4 one another? What was finally the impact of the climatic changes that occurred during the LGIT on the Pyrenean ice extent? Here 
we try to answer these questions through a historiographic presentation of research on Pyrenean glaciation since the end of the 19th century.

\section{The Würmian MIE, starting point of the last deglaciation: a century of research}

The paleogeography and chronology of the Würmian MIE, or maximum icefield boundary, are now well established (Fig. 1; Calvet et al., 2011). These limits are based on one century of mapping of ice-margin deposits. We outline here how the chronological and spatial setting of the Würmian MIE has determined how researchers have conceptualized the process of deglaciation.

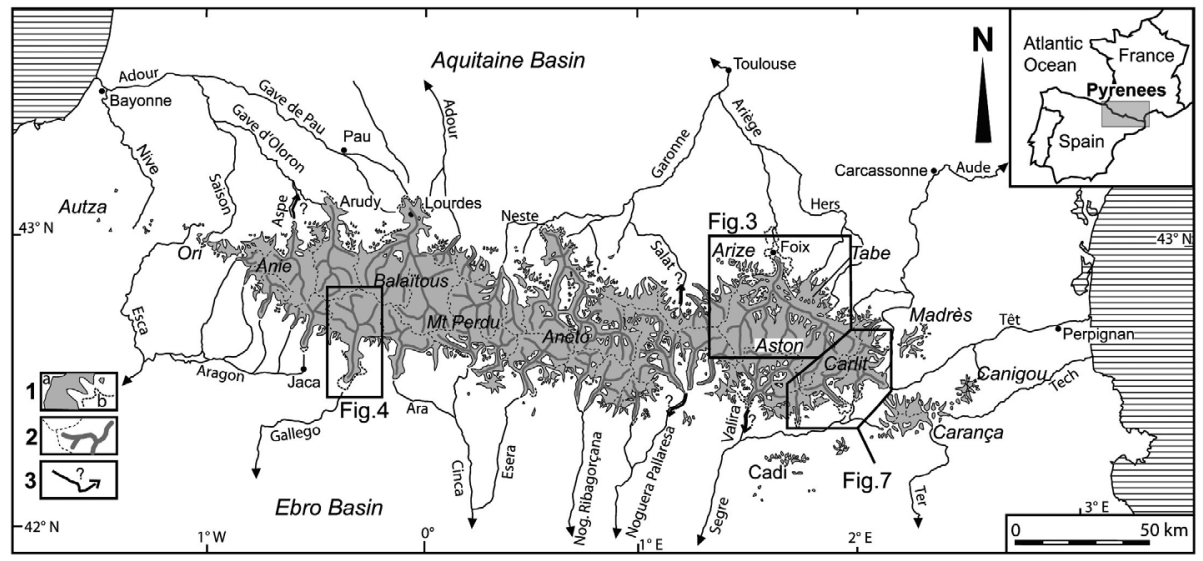

Figure 1. The last Maximum Ice Extent (MIE) in the Pyrenees. Ia-Würmian MIE; b-Middle Pleistocene ice extent. 2- Main supraglacial mountain ridges and ice catchment limits; main iceways. 3-Possible extent of Pleistocene outlet glaciers.

\subsection{The first maps and the dispute between monoglacialists and polyglacialists}

A. Penck published extremely detailed reviews of the glacial landscapes and deposits of the Pyrenees in 1883 and 1894, i.e. 25 years before the publication of the famous synthesis on Alpine glaciations by Penck and Brückner (1909-1910). These early Pyrenean reviews did not address issues of chronology. During the 20th century, the inventory and mapping of ice-margin deposits continued on the north (Mengaud, 1910; Depéret, 1927; Faucher, 1937; Goron, 1941) as well as the south sides of the mountain range (Panzer, 1926, Llopis-Lladó, 1947; Fontboté, 1948). These studies identified three sedimentary units associated with three contrasting ice extents (Viers, 1961; Taillefer, 1963; Barrère, 1963). The "moraines externes", or outermost moraines, locate the maximum extent of the Pleistocene glaciers, whereas the "moraines internes" (or "stades de disjonction") refer to a time after which tributary glaciers became disconnected from the trunk glacier and began to produce their own frontal moraines in the tributary valleys. Finally, the "moraines des cirques" describe the third and final period when the 
ice was confined to the floors of glacial cirques. A similar terminology remained in use on the south side of the range until the early 1990s (Fig. 2).

\begin{tabular}{|c|c|c|c|}
\hline \multirow{2}{*}{ «moraines des cirques» } & «Fases postglacials» & Postglacial & Holocene \\
\hline & «Fase de glaceres rocalloses» & Tardiglacial & \\
\hline $\begin{array}{l}\text { "moraines internes»" } \\
\text { («stade de disjonction») }\end{array}$ & $\begin{array}{l}\text { «Fase de glaceres d'altitud» } \\
\text { «Fase de glaceres de vall» }\end{array}$ & \multirow{4}{*}{ Glacial } & \multirow{4}{*}{ 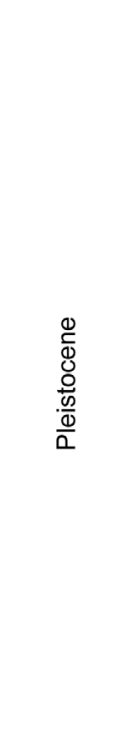 } \\
\hline & «Fase d'estabilització post-màxim» & & \\
\hline \multirow{2}{*}{$\begin{array}{l}\text { «moraines externes») } \\
\text { («phase d'expansion } \\
\text { maximale») }\end{array}$} & «Fase de màxim glacial» & & \\
\hline & «Fases d'estabilització pre-màxim» & & \\
\hline
\end{tabular}

Figure 2. Relative chronostratigraphy of Pyrenean glacial deposits. After Bordonau, 1992, modified.

The issue of allocating ages to the glacial deposits increasingly became a concern, and until the 1980s features such as the state of clast weathering, soil types, and deposit position in the landscape remained the main relative dating criteria. Until the late 1960s, analogies with the Alpine model (or, conversely, reactions against this model) fueled the debate. As a result, the 1950s and 1960s were a time of sharp debates between polyglacialists and monoglacialists.

Among the polyglacialist camp, H. Alimen (1964) claimed to recognize in the valley trains of the North Pyrenean foothills (Gave d'Ossau, Gave de Pau, Adour and Neste d'Aure) the four glaciations that had been identified in the Bavarian foothills of the Alps at the beginning of the century by Penck and Brückner (19091910) -including the Donau glaciation later defined in its type area of the Danube valley (Eberl, 1930). The two higher terraces of the north-Pyrenean foothills were respectively correlated with the Donau and the Günz because they contained an abundance of quartzite clasts and could thus be assimilated to the Alpine Deckenschotter. The third terrace is deeply entrenched below the Günz deposits. The state of clast weathering is less intense than in the case of the previous two levels, but 
the terrace deposit is nonetheless also capped by red soils. These criteria persuaded Alimen (1964) to correlate this third terrace level with the Mindel glaciation because, in the Alps, the Mindel likewise corresponded to the lower known terrace capped by red soils. Finally, again by analogy with the Alpine model, the lower level of north-Pyrenean fluvial sequences is ascribed to the Riss. Furthermore, given that the lower North-Pyrenean terraces are topographically connected to the "moraines internes", Alimen (1964) correlated them with the Riss glaciation, and thus ascribed the "moraines internes" to the Würmian glaciation. Finally, according to Alimen (1964), the Würmian MIE corresponded to relatively small glaciers whose frontal position was located in the elevated parts of the U-shaped valleys, whereas deposits of the last deglaciation were confined to the floors of the cirques and to the crest area.

Among the monoglacialists, the inner and outer moraines were considered as the result of a single glaciation, because the weathering facies of these two units were too similar to be of differents ages (Viers, 1960; Taillefer, 1960; Taillefer, 1961; Barrère, 1963). Moreover, the high and middle terraces of the North-Pyrenean foothills could not be of glaciofluvial origin because neither of those levels grades topographically with the outermost moraines of the glacial sequence (Taillefer, 1951; Viers 1963). These observations and interpretations, spearheaded by G. Viers, produced a model for understanding the Quaternary period that stood in complete contradiction with the works on global paleoclimates published during the 1950s (Emiliani, 1954). According to this model, the Pyrenees experienced only one single glaciation, which occurred at the end of the Pleistocene after a period of fluvial denudation during the Villafranchian and alluvial fan construction and forming the high and middle terraces of the North Pyrenean foothills. Thus, for the monoglacialists, the outermost moraines were a legacy of a "phase d'expansion maximale", while moraines in more internal valley positions were the legacy of a deglacial stage named "stade de disjunction". Lastly, moraines located in the cirques were at first ascribed to the Lateglacial (Viers, 1961, 1963, 1968) and subsequently to a "Neoglacial" period, "si proche des crêtes que la progression dont il résulte a nécessairement été précédée d'une déglaciation presque complète" (Taillefer, 1969, p. 27; Taillefer, 1967).

\subsection{Recent rehabilitation of polyglacialist views and repositioning of the Würmian MIE}

It was not until the beginning of the 1990s, and the first attempts at U-Th-dating the stalagmitic floors of the Niaux-Sabart-Lombrives caves (Sorriaux, 1981, 1982; Bakalowicz et al., 1984), that the multiplicity of successive Pleistocene glaciations was unanimously acknowledged (Taillefer, 1985). A growing number of radiometric ages have been published since (review in Calvet et al., 2011), although none currently span the entire Pleistocene record. This explains why the chronostratigraphy of Pleistocene deposits currently recognized in the Pyrenees is mainly based on relative criteria developed in the 1970s, which relied on the state of weathering and the soil geography of glaciofluvial terrace systems in the North-Pyrenean foothills (Icole, 1973; Hubschman, 1973, 1975a, 1975b, 1975c). These studies reflect a continuity with 
the those conducted a few years earlier in the same area (Alimen, 1964) but they are based on much more advanced analytical datasets because they focus on the finertextured fraction as well as the coarse fraction and relied on methods inspired by existing research on soil chronosequences (Birkeland, 1968, 1999). These weatheringbased approaches allowed the terraces initially ascribed to the Riss and the Mindel to be reassigned instead to the Würm and the Riss, respectively. It has been established on that basis that the Würmian glaciofluvial deposits could be distinguished from their very limited state of weathering, from the sand- and gravel-rich matrix, and from the presence of eluviated brown soils; Rissian deposits (MIS 6), in contrast, were characterized by weathering profiles at least 4 to $5 \mathrm{~m}$ deep, exhibiting a brown to ochre matrix, weakly enriched in clay and free iron, and displaying a coarse fraction consisting of at least $50 \%$ of weathered crystalline pebbles.

This relative chronology of North-Pyrenean glaciofluvial terraces was subsequently and successfully transposed to the outer moraine systems (Hubschman, 1984; Hétu and Gangloff, 1984; Calvet, 1994, 1998). These studies, initially conducted on rivers such as the Gave d'Ossau, Gave de Pau, Garonne and Ariège, show that the boundary between the Rissian and Würmian glaciations does not run between the outer and inner moraines, as initially envisioned by the earlier polyglacialists (Alimen, 1964), but lies within the outer moraine systems. Hubschman (1984), for example, showed that the terminal moraines of the foothill zone contained two generations of till displaying significantly different states of weathering. The "moraines récentes" could be tied to the Würmian glaciation because they show a very limited state of weathering. The majority of the pebbles are unweathered. The matrix consists of coarse sand, is rich in feldspar and mica, and poor in vermiculite. These younger glacial landforms form very well preserved frontal and lateral moraines. They are conspicuous in the landscape and are connect topographically with the lower Würmian terraces of the North-Pyrenean foothill zone. In contrast, the older "moraines anciennes" are characterized by a finer, brown and ochre-colored matrix, poor in plagioclase but rich in vermiculite and showing some advanced weathering features among micaceous minerals. In many valleys on the north side of the range, these weathered moraines remain only as residual patches located relatively close to, but topographically higher than, the "moraines récentes". Likewise, the topographic continuity with the terraces of the foothill zone is not always apparent. Where they exist, however, field evidence shows that the "moraines anciennes" are topographically connected to the middle terraces of the North Pyrenean foothills, i.e. with levels ascribed to the Rissian glacial stage (MIS 6). Based on the seminal contributions of Hubschman (1984), at least two generations of pre-Würmian tills have been identified on the Pyrenan moraines in an outer position (Hétu and Gangloff, 1984; Calvet, 1994, 1998).

In summary, by separating the deposits that are coeval with the last glacial cycle from those that are contemporaneous of previous glaciations on the basis of objective analytical criteria, these studies allowed to the Würmian MIE to be located in several Pyrenean valleys (Fig. 1). However, because there is no obvious weathering gradient between the "moraines récentes" in an outer position and the "moraines internes" 
of the more interior parts of the valleys, these criteria have not allowed a relative chronostratigraphy of the Würmian deposits to be established. Gaining deeper insight into the absolute chronology of glaciation needed more radiometric dating. The first radiocarbon ages from glaciolacustrine deposits provided further insight into the chronological patterns of the last Pyrenean glaciation.

\section{Contributions from radiocarbon dating}

Starting in the 1980s, work on the chronology of the last glacial cycle produced an increasing number of radiocarbon ages. Most of these came from pollen cores acquired primarily for reconstructing the vegetation history since the end of the last Pleniglacial (review in Jalut et al., 1992). Sedimentological analyses were also performed on all the radiocarbon-dated sequences. These data allowed knowledge about the timing of the Würmian MIE and of the following deglaciation to be refined (review in Andrieu et al., 1988). These studies led to a chronological model significantly that was more precise than that supplied by previous relative dating attempts. However, it is important to note that this model indexed on radiocarbon dating was only based on indirect data, i.e. glaciolacustrine clays from cores situated adjacent to Würmian MIE moraines such as at Biscaye, Lourdes, Le Monge, Barbazan, Llestui, and Els Bassots. This is not identical to dating frontal or lateral moraines directly. In all of these settings, the ${ }^{14} \mathrm{C}$ data obtained from the base of the core samples pre-date the Würmian MIE and post-date the onset of deglaciation. The close proximity between the position of the snout of the glacier and the paleolake containing the fill sequence could generally be ascertained by the presence of dropstones in the dated glaciolacustrine clays. However, when dropstones are absent, correlating ice-margin positions with the radiocarbon ages obtained from the glaciolacustrine clay becomes much less robust because proglacial streams, which tend to feed the glaciolacustrine deposits, are capable of transporting suspended load over long distances before ponding forces the particles to settle in the lacustrine sediment trap.

\subsection{A chronology for the north side of the range}

The first age bracket for the Würmian MIE was obtained from the proglacial fill sequence of Biscaye, where the basal glaciolacustrine unit, which contains dropstones, yielded an age of $38.4 \pm 2.0 \mathrm{ka}$ BP (Mardones and Jalut, 1983). A quantification of the sedimentation rate between the two older ${ }^{14} \mathrm{C}$ ages set the age of the fill-sequence base, by extrapolation, to $\sim 45 \mathrm{ka}$. Because this fill sequence is located just behind the Würmian MIE frontal moraine on the Gave de Pau, the authors propose to place moraine construction between 50 and $70 \mathrm{ka} \mathrm{BP}$. Using IntCal13 (Reimer et al., 2013), the calibrated ${ }^{14} \mathrm{C}$ age converts to between 39,541 and 47,932 ka cal. BP. Comparable results have been obtained on the Gave d'Ossau, where the Estarrès fill sequence provided an age of $27.15 \pm 1.0 \mathrm{ka} \mathrm{BP}(29,467$ to $33,761 \mathrm{ka}$ cal. BP) in the glaciolacustrine rythmites at the base of the borehole (Andrieu, 1987; Jalut et al., 1988; Andrieu et al., 1988); and likewise in the Garonne valley, where the Barbazan fill sequence yielded an age of $31.16 \pm 1.7 \mathrm{ka}$ 
BP (32,037 to 39,407 ka cal. BP) in the glaciolacustrine rythmites and diamicton at the base of the core (Andrieu, 1991; Andrieu et al., 1988; Jalut et al., 1992). In the Ariège catchment, a ${ }^{14} \mathrm{C}$ age from the base of the Freychinède borehole has indicated that the Würmian MIE occurred prior to $21.3 \pm 0.76 \mathrm{ka} \mathrm{BP}$, i.e. 24,056 to 27,346 ka cal. BP (Fig. 3, Jalut et al., 1982).

Following this early occurrence of the Würmian MIE, glaciers stagnated for a time in the foothill zone before receding definitively to the higher reaches of the valleys. On the Gave de Pau, although the proglacial fill sequence interrupts at 31.9 $\pm 2.0 \mathrm{ka} \mathrm{BP}$ (Biscaye, 32,657 to $42,182 \mathrm{ka}$ cal. BP), the authors consider that the ice left the foothills only around $29.5 \pm 1.2 \mathrm{ka}(32,246$ to $36,406 \mathrm{ka}$ cal. BP), i.e. at a time when the Biscaye sequence and the neighboring sequences of Lourdes and Le Monge recorded an interruption of proglacial sedimentation. On the Ossau valley, the Estarrès sequence places the deglaciation of the foothill zone between $24.4 \pm 1.0 \mathrm{ka} \mathrm{BP}(27,068$ to $30,974 \mathrm{ka}$ cal. BP) and $18.97 \pm 1.0 \mathrm{ka} \mathrm{BP}(20,809$ to 25,632 ka cal. BP). Data obtained in the Castet fill sequence are similar (Andrieu, 1987; Jalut et al., 1988; Andrieu et al., 1988). On the Garonne valley, the Barbazan sequence places the same event just after $26.6 \pm 0.46 \mathrm{ka} \mathrm{BP}(29,786$ to $31,446 \mathrm{ka}$ cal. BP, Andrieu, 1991; Andrieu et al., 1988; Jalut et al., 1992). Because they are located in the foothills (Biscaye, Estarrès) or in their immediate vicinity (Castet), the information contained in these boreholes is restricted to the earliest stages of the deglaciation. Only two sites (Bious, Gave d'Ossau, 1550 m; Freychinède, Ariège, $1350 \mathrm{~m}$ ) constrain the later stages of deglaciation. The data converge on the idea of a relatively early deglaciation of the upper part of the valleys. Ages of $15.8 \pm 0.24 \mathrm{ka} \mathrm{BP}$ $(18,641$ to $19,719 \mathrm{ka}$ cal. BP) from the base of the Bious fill sequence indicate that the ice had retreated to the cirques located around the Pic du Midi d'Ossau before the beginning of the Oldest Dryas (Fig. 4). This young age, however, remains doubtful given the authors' remarks about the three other ages from farther up in the stratigraphic sequence (Jalut et al., 1988). The Freychinède sequence indicates (i) that the transfluence pass located near the fill sequence, at $1517 \mathrm{~m}$, was free of ice as early as $21.3 \pm 0.76 \mathrm{ka} \mathrm{BP}(24,056$ to $27,346 \mathrm{ka}$ cal. BP); and (ii) that the cirques located on the south side of the Trois Seigneurs massif supplied, at that time, a valley glacier occupying the Suc River valley, a tributary of the Vicdessos valley. The terminal ice margin of this tributary glacier cannot currently be located. Nothing indicates whether or not it joined up with the trunk glacier situated in the Vicdessos valley. Nonetheless, the presence of sillimanite in the glaciolacustrine sediments, from the bottom of the borehole to a depth of 396-398 cm, show that the Suc valley glacier was sufficiently thick to feed the Freychinède paleolake with juxtaglacial meltwater from metamorphic outcrops in the massif des Trois Seigneurs. (iii) After $13.15 \pm$ $0.3 \mathrm{ka}$ BP (14,859 to $16,796 \mathrm{ka} \mathrm{cal}$. BP, dating obtained at a depth of $401-403 \mathrm{~cm})$, the interruption of sillimanite-rich detrital inputs indicates that the Suc glacier no longer extended beyond the bedrock step located at 1360-1380 m a.s.l. between the Suc valley and the Freychinède fill sequence. The authors consider that, from that time, the ice was confined to the floor of the cirques located on the south side of the Trois Seigneurs massif (Fig. 3, Jalut et al., 1982). 

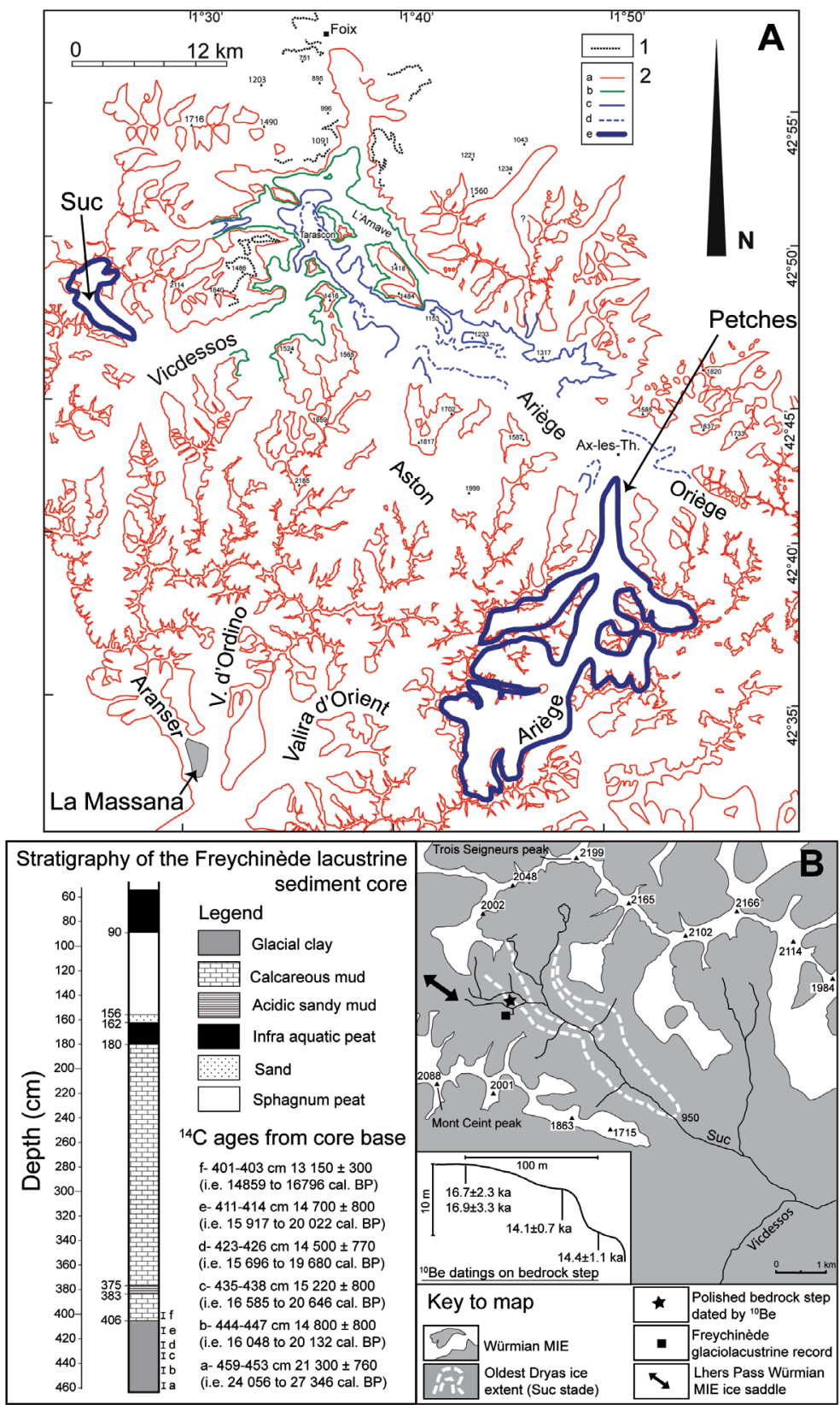

Figure 3. Pleistocene ice extent in the Ariège catchment. A. 1- Pre-Würmian ice extent. 2Paleogeography of the Würmian MIE (a) and of the Garrabet (b), Bompas-Arignac (c), Bernière (d), and Petches and Suc (e) stades. 3- Pre-Würmian erratic boulders dated by cosmogenic ${ }^{10} \mathrm{Be} .4-{ }^{10} \mathrm{Be}$ sampling site on a Würmian moraine (site $E$ is a proglacial alluvial fan connected to the Garrabet terminal moraine). $5-{ }^{10}$ Be bedrockstep sampling site. Map after Delmas et al. (2012) and Calvet

et al. (2011). B. Lateglacial ice extent in the Suc valley. After Delmas et al., 2011, modified. 


\subsection{A coherent chronology for the south side of the range}

The ${ }^{14} \mathrm{C}$ ages obtained in the glaciolacustrine fill sequences of the south side of the range, particularly those in the Noguera Rigorçana valley (Fig. 5), have previously confirmed the chronological model elaborated for the north side. New data inconsistent with the initial results have, however, rekindled the debate started by Turner and Hannon (1988) over whether or not the Pyrenean Würmian MIE and the global isotopic record were truly synchronous (review in Pallàs et al., 2006). In 1983, the base of the Llestui fill sequence was dated and produced an age of ca. $33 \mathrm{ka}^{14} \mathrm{C} \mathrm{BP}$ (Vilaplana, 1983a; Vilaplana and Bordonau, 1989). Later, Bordonau (1992) dated the base of the Els Bassots proglacial fill sequence and produced an age of $31.41 \pm 1.2 \mathrm{ka} \mathrm{BP}(33,542$ to $38,941 \mathrm{ka} \mathrm{cal}$. BP). However, the author highlighted inconsistencies among the ${ }^{14} \mathrm{C}$ ages from the fill base and doubted any synchroneity with the chronological model developed on the north side of the range. The following year, noting a number of further inconsistencies in the ${ }^{14} \mathrm{C}$ data obtained in the Llestui fill sequence (Vilaplana, 1983a; Vilaplana and Bordonau, 1989), Bordonau et al. (1993) undertook to redate the samples. In order to take into account the presence of mineral graphite in the catchment ("old carbon" effect), the authors developed a protocol for sample preparation with the purpose of separating the organic carbon from the mineral carbon. At the end of this treatment, the results turned out to be clearly younger, and the "phase de stabilisation post-maximum" was restored to an age lying between $18.24 \pm 0.6(20,684$ to $23,600 \mathrm{ka}$ cal. BP) and $21.65 \pm 0.9 \mathrm{ka} \mathrm{BP}$ (24,113 to $27,831 \mathrm{ka}$ cal. BP). Following this revision of radiocarbon ages on the south side of the range, new boreholes were also drilled in the Biscaye, Lourdes and Le Monge fill sequences of the north side (Reille and Andrieu, 1995). However, only the Lourdes 1 borehole yielded ${ }^{14} \mathrm{C}$ ages relevant to this study. Indeed, the age obtained in the blue glaciolacustrine clays at the base of the borehole provided an age of 20,025 $\pm 0.175 \mathrm{ka}$ BP (23,700 to 24,557 ka cal. BP), suggesting that the Würmian MIE could be much younger than previously considered on the basis of Biscaye datings. However, the age obtained from the base of the overlying gyttja also showed that glaciolacustrine sedimentation ended before $15.46 \pm 0.15 \mathrm{ka} \mathrm{BP}(18,436$ to $19,076 \mathrm{ka}$ cal. BP) and that the glacier was, by that time, confined to the higher part of the valley.

The ${ }^{14} \mathrm{C}$ ages obtained from the glaciolacustrine fill sequence of the Gállego valley (Paul de Bubal, Ibon de Tramacastilla, Nord Tramacastilla, Fig. 4) are highly consistent with the data obtained on the north side of the range. The paper by García-Ruiz et al. (2003) was accordingly entitled "Asynchroneity of maximum glacier advances in the central Spanish Pyrenees" in reference to other European mountains. The reasoning is based on sedimentary sequences from paleolakes linked to various deglacial stades. Several ages obtained from the base of the boreholes led the authors to consider the Gállego Würmian MIE to be older than the Global LGM, even older than MIS 2. Note that the age at $29.4 \pm 0.6 \mathrm{ka} \mathrm{BP}$ (32,030 to $34,736 \mathrm{ka}$ cal. BP) obtained in the glaciolacustrine unit at the base of the Ibon de Tramacastilla sequence was considered unreliable by the authors, who considered the likelihood of the "hard water" and/or "old carbon" effects. A new borehole from the same ice-marginal paleolake (North Tramacastilla borehole: depth $4 \mathrm{~m}$, against $14 \mathrm{~m}$ for Ibon de Tramacastilla borehole) yielded an AMS ${ }^{14} \mathrm{C}$ age in proglacial silt, $275 \mathrm{~cm}$ from the surface, of $20.6 \pm 0.17 \mathrm{ka} \mathrm{BP}$ (i.e. 24,389 to $25,345 \mathrm{ka}$ cal. BP). The authors considered the latter age 
to be more reliable than another of $29.4 \pm 0.6 \mathrm{ka}$ BP because it was obtained from a pollen assemblage rich in terrestrial taxa. According to those authors, this precaution minimizes the "hard water" effect (which artificially increases radiocarbon ages). However, it is important to emphasize that this new age can nonetheless not be directly compared to the initial result because the two samples were collected from different boreholes and thus do not date exactly the same sedimentary unit.

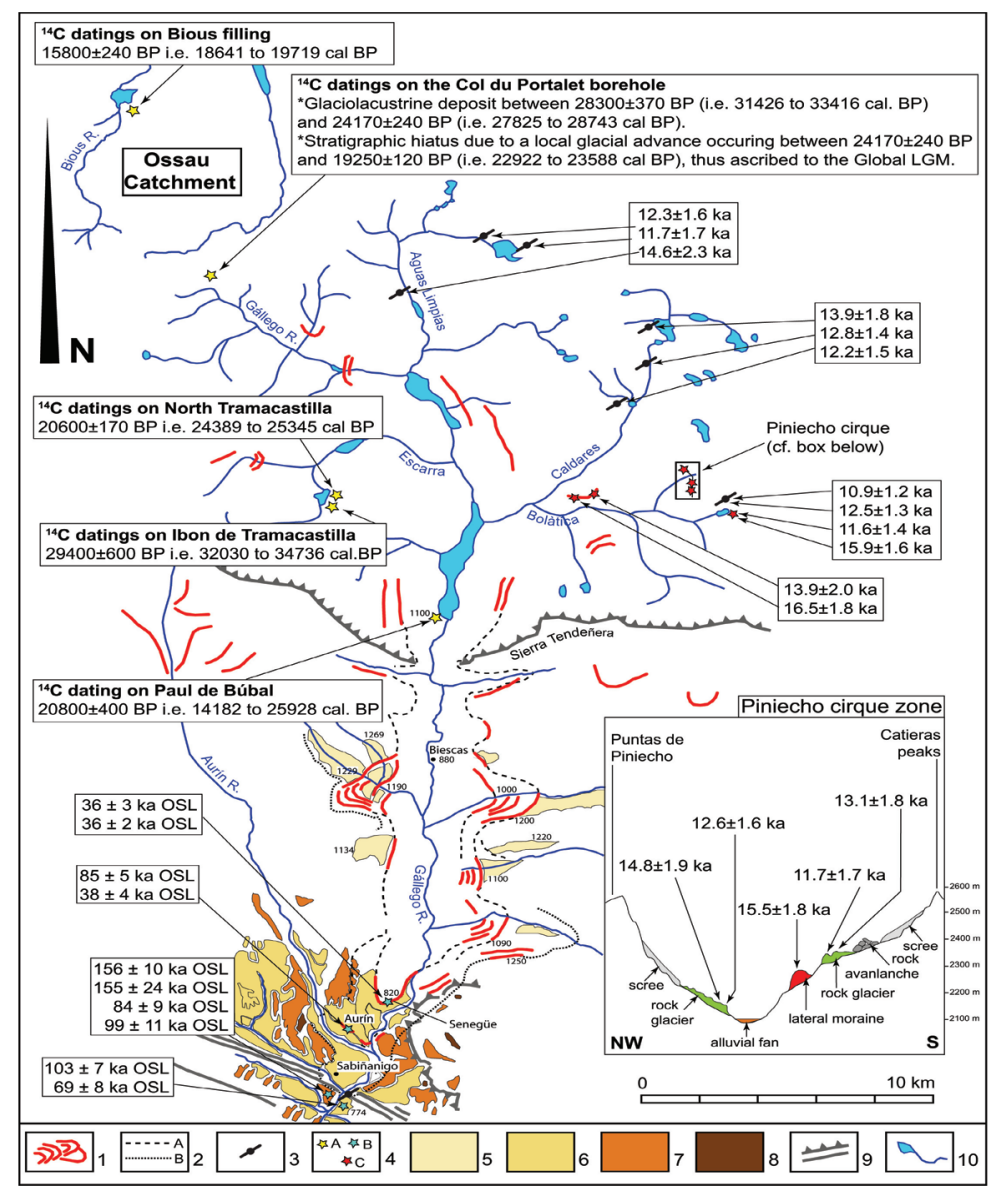

Figure 4. Glacial and glaciofluvial deposits, with associated exposure ages in the Gállego catchment. 1- Frontal and lateral moraines. 2A-Successive Würmian ice-margin positions, $B$ - Middle Pleistocene (MIS 6) ice-margin position. 3-Scoured rock surfaces on bedrock steps. 4A- Location of ${ }^{14} \mathrm{C}$ sample ages, $B$ - OSL sample ages, $C$ - ${ }^{36} \mathrm{Cl}$ sample ages. 5- Würmian icecontact sedimentary units (lacustrine or fluvial). 6- Proglacial alluvial trains, poorly weathered (Qt6-7-8). 7- Proglacial alluvial trains and mantled wash pediments, weathered and rubefied (Qt5). 8- Highest alluvial deposits. 9- High-relief landforms. 10- Lakes and drainage network.

Dated OSL sites (66 $\pm 4 \mathrm{ka}$ : Hostal de Ipies; $74 \pm 10 \mathrm{ka}$ : Llano de Yeste) are located 1 and 5 $\mathrm{km}$ from the town of Sabiñanigo, respectively (i.e. beyond the southern limit of the figure). After Palcios et al. (2015b) and Calvet et al. (2011). 
Although the Gállego sites were selected and sampled mainly in order to discuss the age of the Würmian MIE, their location in the upper part of the glacial catchment makes them also interesting in terms of timing of the last deglaciation. Indeed, (i) the ${ }^{14} \mathrm{C}$ ages of the glaciolacustrine unit of the Paul de Bubal sequence (Jalut et al., 1992) show that the Gállego glacier was located at least $15 \mathrm{~km}$ upstream the Senegüe frontal moraine before $20.8 \pm 0.4 \mathrm{ka} \mathrm{BP}\left(24,182\right.$ to $25,928 \mathrm{ka}$ cal. BP). (ii) The ${ }^{14} \mathrm{C}$ ages obtained from the Tramacastilla boreholes (Ibon de Tramacastilla and Nord Tramacastilla) record the end of the transfluence between the Lana Major and the Escarra iceways, and also the probable disconnection between these two joined-up catchments and the main Gállego outlet glacier. Finally, (iii) the Portalet peatbog, which is located in a tributary of the Gállego within the cirque area between 2100 and $2300 \mathrm{~m}$, benefited from the multi-proxy study of a 6.64 m core (González-Sampériz et al., 2006). The sedimentary sequence shows a stratigraphic hiatus marked by an erosional surface, a sharp break in the pollen spectra, and a very low rate of sedimentation. This stratigraphic hiatus overlies a glaciolacustrine deposit AMS-dated between $28.3 \pm 0.37 \mathrm{ka} \mathrm{BP}(31,426$ to 33,316 ka cal. BP) and $24.17 \pm$ $0.24 \mathrm{ka}$ AMS BP $(27,825$ to $28,743 \mathrm{ka}$ cal. BP). It is followed by a continuous sedimentary sequence characterized by alternating silt levels varyingly enriched in carbonates and organic matter, and topped by $2 \mathrm{~m}$ of peat. The sedimentary sequence provides a continuous record of the vegetation history from $19.25 \pm 0.12$ ka AMS BP $(22,922$ to $23,588 \mathrm{ka}$ cal. BP) until the middle of the Holocene (5 ka). It also indirectly documents the timing of the glacial fluctuations around the site. The basal unit, which is AMSdated between $28.3 \pm 0.37$ and $24.17 \pm 0.24 \mathrm{ka} \mathrm{BP}$, is coeval with an interstadial during which the upper valley around the peatbog was occupied by small glaciers confined to the cirque floors situated in the catchment above the paleolake. Between $24.17 \pm 0.24$ and $19.25 \pm 0.12 \mathrm{ka}$ AMS BP, the authors reconstructed two successive events. (i) The stratigraphic hiatus is associated with a glacial advance ascribed to the Global LGM. After $24.17 \pm 0.24$ AMS BP, the glaciers were confined to the cirque floors but advanced into the valley and overrode the paleolake. However, there is no evidence that this glacial advance reached the Gállego trunk glacier. (ii) The sedimentary sequence that overlies the stratigraphic unconformity shows that, ca. 19.25 \pm 0.12 ka AMS BP $(22,922$ to 23,588 ka cal. BP), the area around the Portalet peatbog was once again ice-free. However, given the lack of proglacial sedimentation in the post-erosional fill sequence, this time the ice had probably receded as far back as the iceshed. The authors note that all ${ }^{14} \mathrm{C}$ AMS ages were obtained from pollen assemblages rich in terrestrial taxa in order to minimize the risk posed by the "hard water" effect. To summarize, the data obtained throughout the Gállego glacial catchment are internally consistent, especially taking into account that the Tramacastilla and Portalet paleolakes are located in tributaries of the Gállego valley less well supplied than ice flow from the Sallent and Panticosa massifs -where the higher summits reach $3000 \mathrm{~m}$ and may have fed a large glacier at a time when the Tramacastilla and Portalet sites were already ice-free.

Farther east, sequence stratigraphy and ${ }^{14} \mathrm{C}$ AMS ages from La Massana paleolake in Andorra (Turu i Michels, 2002) allow the timing of the first steps of the last deglaciation in the Andorran valleys to be reconstructed (Fig. 3). During the Würmian MIE, Andorra was covered by a large composite outlet glacier fed by the 
confluence of the Valira d'Orient (Gran Valira) and the Valira del Nord tributaries -the latter being itself fed from the confluence between the local valley glaciers of Arinsal and Ordino. La Massana paleolake is thus contemporaneous of a deglacial stade during which the Arinsal and Ordino were confined to their upper valleys, while the Valira d'Orient was still large enough to obstruct the Valira del Nord. The sequence stratigraphy of the paleolake fill sequence has allowed changes in paleolake water levels, and thus changes in the Gran Valira ice thickness, to be inferred. It has also provided a record of climate-driven fluctuations of the local Arinsal and Ordino glaciers, which overrode the paleolake deposits at regular intervals. Numbers of ${ }^{14} \mathrm{C}$ AMS ages obtained in this fill sequence place the disconnection of the two Valira valley glaciers and ponding of the paleolake before $25.64 \pm 0.19$ ka BP $\left(19,352\right.$ to $30,482 \mathrm{ka}$ cal. BP). One ${ }^{14} \mathrm{C}$ age on organic colluvium drilled in the giant landslide of El Forn (Canillo) indicates that the disconnection between the two Valira occurred before $34.25 \pm 0.32 \mathrm{ka} \mathrm{BP}$ (i.e. 38,151 to $39,667 \mathrm{ka}$ cal. BP, Planas et al., 2011). At this time, the ice terminal position of the Valira d'Orient was located $25 \mathrm{~km}$ upstream of the MIE terminal position. Thereafter, the Massana record shows a relative persistence of the paleolake until about $15.49 \pm 0.07 \mathrm{ka}$ AMS BP $(18,617$ to $18,909 \mathrm{ka}$ cal. BP). This shows that the Global LGM glacial advance, which is recorded by a prograding till in the sedimentary sequence, did not reach the position of the Würmian MIE. A glacial advance was also recorded during the Oldest Dryas, but after $15.49 \pm 0.07 \mathrm{ka}$ AMS BP $(18,617$ to $18,909 \mathrm{ka}$ cal. BP) the definitive interruption of glaciolacustrine sedimentation in the Massana basin indicates that the Valira d'Orient glacier was, by that time, confined to the higher part of the valley.

Two other high-elevation sites confirm an early deglaciation of the Pyrenees compared to other north-European mountains. In the Noguera de Tor valley, the glaciers were confined to the cirques located upstream from Estany Redó d'Aigues Tortes (2110 m d'altitude, Fig. 5) from the Oldest Dryas onward, as shown by an AMS age of $13.47 \pm 0.06 \mathrm{ka} \mathrm{BP}(16,045$ to $16,500 \mathrm{ka}$ cal. BP) in the basal glaciolacustrine unit of the borehole (Copons and Bordonau, 1996). Even more telling data were acquired in the Eastern Pyrenees, at the Grave site $(2150 \mathrm{~m})$ in the upper part of the Têt valley just below the cirque zone, where a buried peatbog yielded three ${ }^{14} \mathrm{C}$ highly consistent ages (Fig. 6). These data indicate that glaciation was confined to the cirques as early as 19-20 ka cal. BP, i.e. before the beginning of the LGIT (Delmas, 2005; Delmas et al., 2008). The authors ascribed this major event to one of the multiple temperate oscillations that characterize the GS-2b stadial of the INTIMATE stratigraphy (Svensson et al., 2008).

\section{Contributions from cosmogenic nuclides and OSL dating}

In the 21st century, dating methods became more diversified. OSL data from the moraine and glaciofluvial systems of the Cinca and the Gállego (Sancho et al., 2003, 2004; Peña et al., 2004; Lewis et al., 2009), the Valira (Turu i Michels and Peña Moné, 2006) and the Aragon valleys (García-Ruiz et al., 2013) were published. At the same 
time, Würmian glacial stades of several Pyrenean valleys became the focus of dating using the in situ-produced cosmogenic nuclides ${ }^{10} \mathrm{Be}$ and ${ }^{36} \mathrm{Cl}$ (Pallàs et al., 2006, 2010; Delmas et al. 2008; Delmas et al., 2011; Palacios et al., 2015a, 2015b). These methods have reinforced the conclusion that the Würmian MIE occurred during MIS 4. They have also provided a glimpse into the complexity of the glacial fluctuations that occurred during the LGIT. The increasingly large number of data promoted by the ubiquitous character of the sampling targets (rock surfaces containing quartz in the case of the nuclides ${ }^{10} \mathrm{Be}$ and ${ }^{36} \mathrm{Cl}$, sand lenses in glaciofluvial or till deposits in the case of OSL) have gradually led researchers to develop a more elaborate chronological model of the last deglaciation in the Pyrenees. The key result is that Würmian and LGIT glaciers were much more unsteady than previously considered just on the basis of ${ }^{14} \mathrm{C}$ dating.

\subsection{OSL data confirm the antiquity of the Würmian MIE (MIS 4)}

OSL data acquired on the south side of the range have been obtained from the sequence of glaciofluvial terraces located in the foothill zone. The high and middle terraces have been ascribed to MIS 6, and even to MIS 8 in the Aragon valley. On the poorly weathered Würmian glaciofluvial levels of the Cinca, Gállego and Aragon valleys, OSL dating has focused on glaciofluvial terraces as well as terminal moraines. In the Cinca valley, the Salinas till and its connected Qt7 terrace indicate a weighted average age of $64 \pm 11 \mathrm{ka}$ (3 OSL ages) and of $61 \pm 4 \mathrm{ka}$ (6 OSL ages), respectively. In the Gállego valley, the Aurín moraine, which was formed during the Würmian MIE, is dated at $85 \pm 5 \mathrm{ka}$ (another OSL age of $38 \pm 4 \mathrm{ka}$ was discarded by the authors), but the Sabiñanigo terrace (Qt7), which is situated in the downstream continuation of the Aurín till, yielded a weighted average age of $68 \pm 7 \mathrm{ka}$ (based on 3 OSL results: $69 \pm 8 \mathrm{ka}$ at Sabiñanigo, $66 \pm 4 \mathrm{ka}$ at Hostal de Ipies, and $74 \pm 10 \mathrm{ka}$ at Llano de Yeste). The frontal moraine of Senegüe, which is located $2 \mathrm{~km}$ upstream from the Aurín moraines, has been dated to $36 \pm 3 \mathrm{ka}$ (two OSL ages by Lewis et al., 2009, Fig. 4). Finally, data acquired from the Aragon valley are relatively similar to those acquired in the Cinca valley given that the moraine corresponding to the Würmian MIE yielded an age of $67 \pm 8 \mathrm{ka}$ (single OSL age by García-Ruiz et al., 2013).

\subsection{Cosmogenic ages cover the entire Würmian glacial sequences}

Whereas OSL data only concern the moraines of outlet glaciers in outer foothill positions, cosmogenic dating in the Pyrenees has begun to cover the entire Würmian sequences from the Würmian MIE moraines to the moraines of the cirque headwaters. All the data acquired in the Pyrenees by this method come either from samples of glacially polished bedrock surfaces or from exposed boulders on moraine crests. Ages obtained on glacially scoured bedrock surfaces document the time when retreating ice exposed the bedrock step for the first time. Ages obtained on moraine boulders indicate the time of moraine abandonment and stabilization due to glacier retreat (Zreda and Phillips, 1994, 1995; Putkonen and O'Neal, 2006; Putkonen et al., 2008). In all cases, the cosmogenic data provide minimum exposure ages because 
the method postulates that sampled surfaces have undergone no erosion since their initial exposure. This assumption is acceptable when supported by suitable field evidence, hence the value of sampling large boulders situated on high and wellpreserved moraines.

\subsubsection{Confirmation for the antiquity of the Würmian MIE, and first evidence of the terminal position of Pyrenean outlet glaciers during the Global LGM}

The first ages for the Würmian MIE obtained in the Noguera Ribagorçana and Têt river valleys (Pallàs et al., 2006, Delmas et al., 2008) do not come from the outermost Würmian moraines but from moraines located a few hundred meters up-valley (Fig. 7). Ages of 21-22 ka obtained on these moraines were briefly poised to re-open the debate on the possibility of a time lag between the Pyrenean Würmian MIE and the Global LGM. This time, however, the debate was short-lived because, as soon as 2010 and 2011, new cosmogenic ages from the Querol, Malniu, and Ariège river valleys showed that, at least in the eastern Pyrenees, MIS 4 terminal moraines stood very closed to those attributable to the Global LGM (Pallàs et al., 2010; Delmas et al., 2011). On that basis, Delmas et al. (2011) considered that the Pyrenean outlet glaciers during MIS 4 and during the Global LGM reached almost similar positions in Pyrenean massifs under Mediterranean climatic influence. Meanwhile, in the western part of the range, i.e. in massifs under Atlantic influence, glaciers during the Global LGM were substantially shorter than during MIS 4. It is thus conceivable that, during the Global LGM at this latitude, cyclogenesis in the Western Mediterranean was more intense and more effective at producing snowfall than North Atlantic weather systems. Concurring evidence has been independently suggested by the sea-surface temperatures recorded for the Global LGM in the Balearic waters (with $9-10^{\circ} \mathrm{C}$ winter and $14-16^{\circ} \mathrm{C}$ summer averages) and the Bay of Biscay $\left(2.1\right.$ to $3.2^{\circ} \mathrm{C}$ in winter, 11.8 to $13.3^{\circ} \mathrm{C}$ in summer, Hayes et al., 2005; de Vernal et al., 2005, 2006). This nonetheless remains a partial assumption because the real terminal position of the Pyrenean glaciers during the Global LGM is still not fully constrained in a number of valleys of the western Pyrenees -for example all the valleys located west of the Ariège. Radiocarbon ages acquired in the 1980s and the 1990s indicate an early deglaciation of the foothill zone, even before the Global LGM (see section 2.1). These, however, are indirect data and should be clarified. Cosmogenic ages have been produced on the outer moraines of the Gave de Pau, precisely for this purpose (Rodes, 2008). Results were not up to expectation because Holocene climatic conditions in the North-Pyrenean foothills exhibit quite intensely weathered rock surfaces, particularly on boulders. Given that post-glacial erosion rates since initial exposure remain unknown, the true exposure ages of the boulders located on the Würmian MIE terminal moraine of the Gave de Pau have not been definitively established. On the south side of the range, the position of the Global LGM terminal moraines has been identified in the easternmost massifs of the range (southeastern side of the Carlit massif, Querol, Malniu, Duran, Llosa, and Arànser: Delmas et al., 2008; Pallàs et al., 2010; Palacios et al., 2015a, Fig. 7) and on the Noguera Ribagorçana (Pallàs et al., 2006, Fig. 5). There is no direct evidence yet from valleys situated farther to the west. 


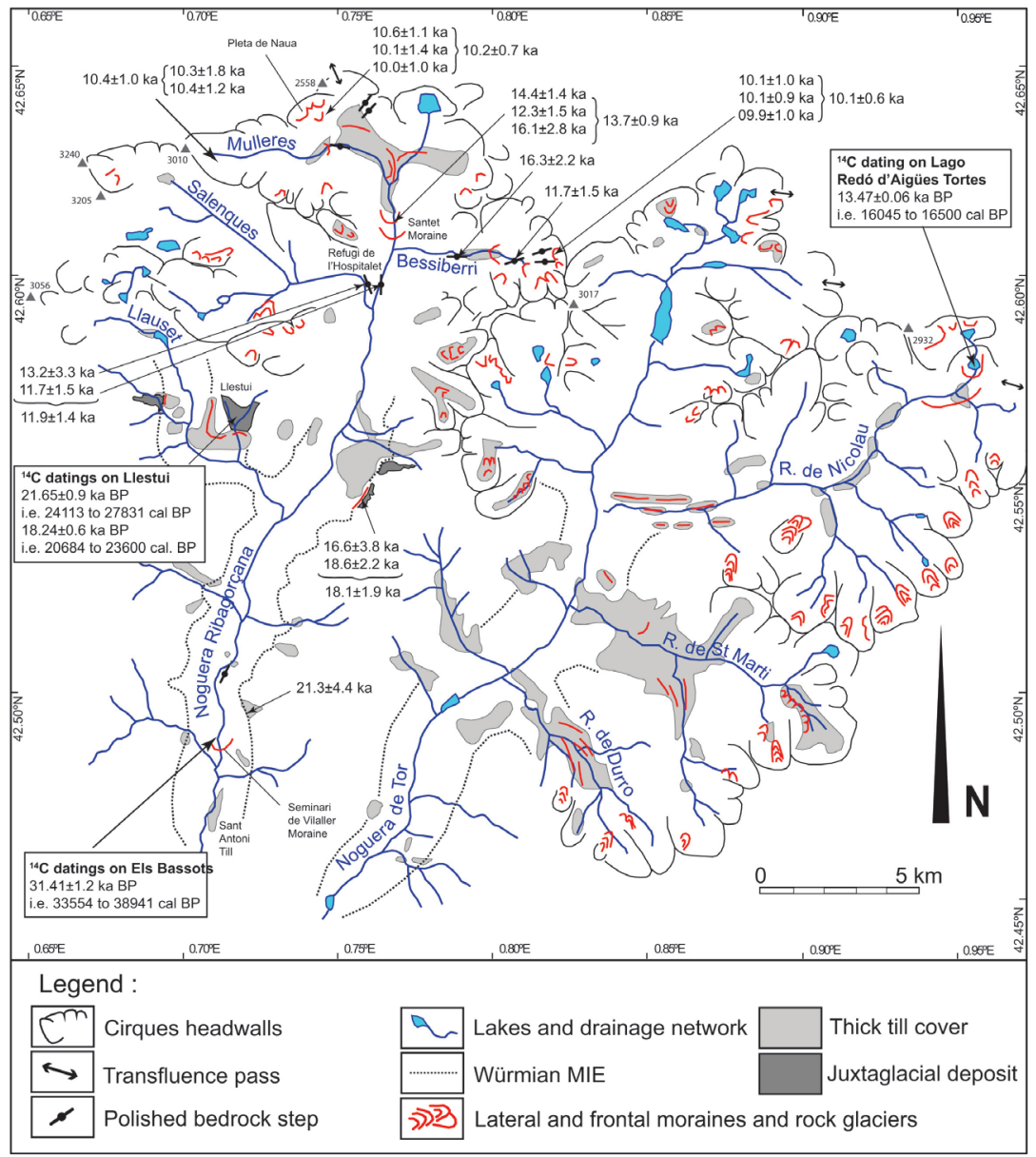

Figure 5. Glacial deposits and their associated ages in the Noguera Ribagorçana and Noguera de Tor catchments. After Vilaplana (1983b) and Pallàs et al. (2006).

\subsubsection{Instability of Würmian ice-margin positions: preliminary evidence}

Evidence of inherited nuclides on polished bedrock steps has revealed the existence of large fluctuations (10 km at least) of the Ariège glacier during MIS 3. Because these occurrences of inheritance are located upstream of the Global LGM frontal moraines, they indicate that the Ariège glacier was affected during MIS 3 by one or several recessional episodes that shortened the outlet glacier by at least $10 \mathrm{~km}$ from the Würmian MIE terminal position. This shows that the post-MIS 4 history of Pyrenean glaciation is more complex than previously detected by ${ }^{14} \mathrm{C}$ dating. Radiocarbon ages obtained from glaciolacustrine fill sequences have tended to convey a spurious understanding of the last glacial cycle as a simple event involving a single glacial advance, which reached a single maximum ice extent, followed by a single phase of deglaciation, interspersed with 
brief episodes of stagnation or short-range advances during which a suite of frontal and lateral moraines were constructed. All ages directly acquired on ice-margin deposits implicitly lead to the same kind of deglacial model. For example, on the Gállego River, the Senegüe moraine, which has been correlated with MIS 3, could be interpreted as the first deglaciation stade that followed the Würmian MIE (i.e. MIS 4, as indicated from Aurín moraines). We know now that this was not the case and that Pyrenean glacier fluctuations, particularly during MIS 3, underwent variations that could be as numerous as those that have been identified on a global scale. The bias comes from the fact that frontal and lateral moraines located upstream from the Würmian MIE terminal moraines have been used to mark deglacial stadials when, in fact, they were constructed during phases of stagnation or, in some case, of glacier readvance.

A similar problem arose after the Global LGM. Several indications suggest that a major and extremely fast deglaciation of the Pyrenean valleys occurred between the Global LGM glacial advance and the beginning of the LGIT. The more direct evidence has been provided by ${ }^{14} \mathrm{C}$ ages obtained from the buried Grave peatbog (Fig. 6), where the three concordant ages of ca. $20 \mathrm{ka}$ cal BP have shown that the Têt glacier was confined to the cirques as soon as the end of the Global LGM while, a few thousands of years before, probably ca. 21-22 ka, the terminal position of the Têt glacier was located $16 \mathrm{~km}$ upstream from the Grave site, i.e. near the Würmian MIE terminal position (Delmas, 2005; Delmas et al., 2008 Fig. 7). In the Querol valley, cosmogenic ages of 19 to $20 \mathrm{ka}$ obtained on bedrock steps situated 3, 5 and $9 \mathrm{~km}$ upstream the Global LGM frontal mo raine, respectively, plead for similar conclusions (Pallàs et al., 2010). Elsewhere, the real magnitude of this phase of early post-LGM deglaciation is not directly recordable.

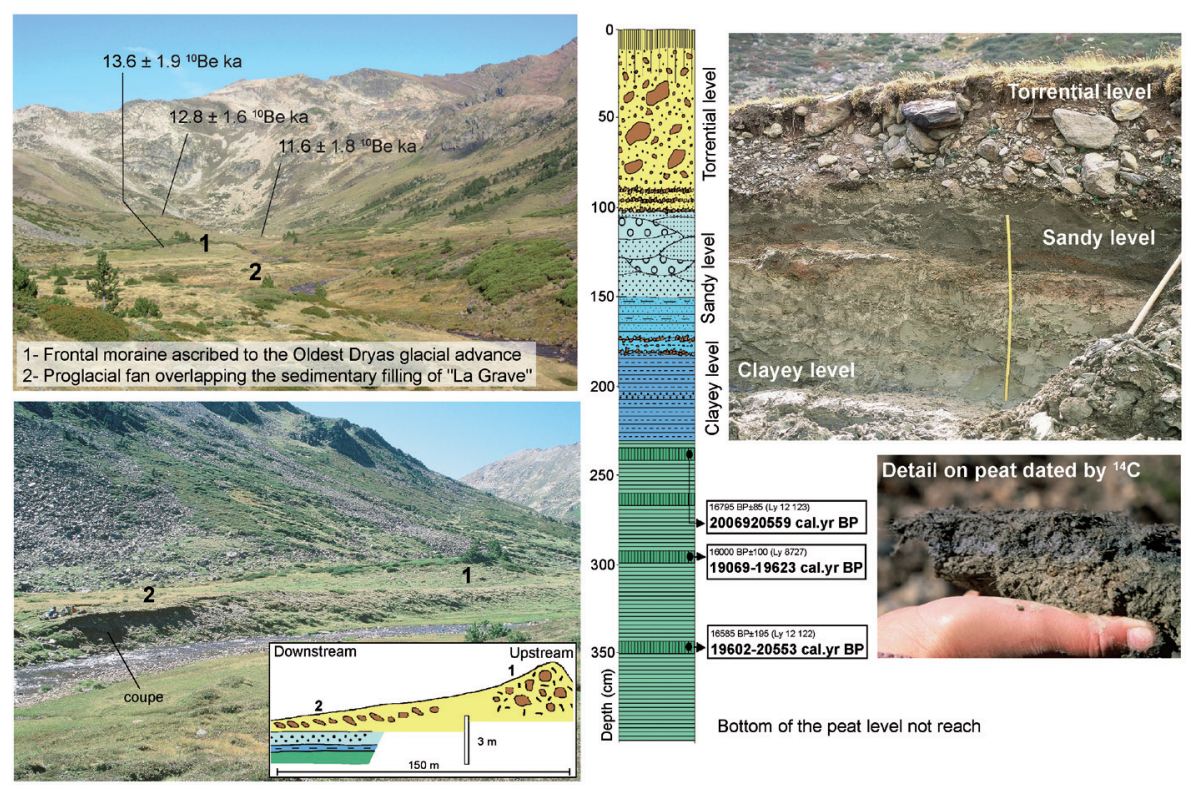

Figure 6. ${ }^{14} \mathrm{C}$ and ${ }^{10} \mathrm{Be}$ ages at La Grave (upper Têt River valley). 


\subsubsection{New data on Pyrenean glaciation during the LGIT}

Cosmogenic data acquired over the past few years have significantly enhanced the body of available data on Pyrenean glaciation during the LGIT. Their number is still limited, but they have helped to locate the ice-margin positions of the Lateglacial glaciers in several valleys more precisely and, on this basis, help to compare them with the positions of the Würmian MIE. Figures 3, 4, 5 and 7 show the drastic reduction of the areas concerned. Cosmogenic exposure ages recently obtained from deposits generated by small glaciers of the easternmost part of the range (Têt, Querol, Malniu, Duran, Llosa, Arànser: Delmas et al., 2008; Pallàs et al., 2010; Palacios et al., 2015a), but also by the Noguera Ribagorçana (Pallàs et al., 2006), Ariège (Delmas et al., 2011) and Gállego glaciers (Palacios et al., 2015b), confirm and reinforce the impression conveyed from previous ${ }^{14} \mathrm{C}$-based conclusions.

The main advantage of cosmogenic data over other dating methods is that they provide an opportunity for dating all the stadials present in a valley, with a potential for attaining a finer resolution of paleoclimatic fluctuations during the LGIT than previously allowed by radiocarbon. However, the relative imprecision and the very nature of the cosmogenic data (which provide exposure ages) do not always allow moraines ascribable to the Oldest Dryas, the Younger Dryas and the Holocene to be distinguished with statistical confidence. Likewise, a comparison of the ages obtained from different Pyrenean valleys would require an uniformization of existing and future data on the basis of the latest calibration standards (NIST SRM 4325 for ${ }^{10} \mathrm{Be}$ dating, Nishiizumi et al., 2007). Nevertheless, a consistent pattern is beginning to emerge despite the limited number of valleys investigated until now.

In the Noguera Ribagorçana valley (cf. Fig. 5, Pallàs et al., 2006), the most consistent results concern the moraines located on cirque floors in the upper part of Bessiberri valley $(2700 \mathrm{~m})$, and around the Pleta Naua (2200 to $2400 \mathrm{~m})$ where 6 cosmogenic ages on boulders yielded weighted average ages of $10.1 \pm 0.6 \mathrm{ka}(9.9 \pm 1.0 \mathrm{ka}, 10.1 \pm 0.9$ $\mathrm{ka}, 10.1 \pm 1.0 \mathrm{ka})$ and of $10.2 \pm 0.7 \mathrm{ka}(10.0 \pm 1.0 \mathrm{ka}, 10.1 \pm 1.4 \mathrm{ka}, 10.6 \pm 1.1 \mathrm{ka})$, respectively. The Mulleres moraine, which records the position of a $3 \mathrm{~km}$ long glacier, has provided a weighted average age of $10.4 \pm 1.0 \mathrm{ka}$, i.e. almost identical to an age obtained on a boulder at $10.4 \pm 1.2 \mathrm{ka}$ and another on a polished bedrock step at $10.3 \pm$ $1.8 \mathrm{ka}$. Downstream of these Holocene (or Younger Dryas -because cosmogenic ages are minimum exposure durations) moraines, the results obtained from the Noguera Ribagorçana are less uniform and more difficult to interpret. The Santet moraine, which is located $4 \mathrm{~km}$ downstream of the Mulleres moraine, has provided three ages at $14.4 \pm$ $1.4 \mathrm{ka}, 12.3 \pm 1.5 \mathrm{ka}$, and $16.1 \pm 2.8 \mathrm{ka}$ on three different boulders. Because the error bars nonetheless overlap, the authors argue for a weighted average age of $13.7 \pm 0.9 \mathrm{ka}$ and use this result to date the disconnection between the Bessiberri and the upper Noguera Ribagorçana glaciers (Pallàs et al., 2006). Farther downstream, the anomalously young exposures ages $(13.2 \pm 3.3 \mathrm{ka}$ and $11.7 \pm 1.5 \mathrm{ka})$ obtained from the Refugi de l'Hospitalet bedrock step are perhaps explained by a patch of till which would have covered the sampled rock surfaces for some period of time after the deglaciation of the bedrock step. Till patches on bedrock steps, however, are intrinsically labile, and post-glacial erosion 
is likely to clear these materials quite soon after deglaciation. Due to this uncertainty, it is thus equally conceivable that the Refugi de l'Hospitalet bedrock step was covered during the Older Dryas by a glacier whose terminal position cannot be precisely located. Finally, the age of the Bessiberri moraine is more difficult to establish because only two ages have been obtained from polished bedrock steps. One is located downstream (16.3 \pm $2.1 \mathrm{ka})$, and the other upstream $(11.7 \pm 1.5 \mathrm{ka})$. These ages are consistent with one another but do not indicate whether the Bessiberri glacial advance occurred during the Oldest Dryas or during the Younger Dryas.

As in the Noguera Ribagorçana, cosmogenic exposure ages in the Têt valley -whether obtained on moraines or on polished bedrock steps-are never perfectly uniform and it is often difficult to decide between the lower age bracket, which would indicate Younger Dryas, and the higher bracket, which indicate Oldest Dryas ages (Fig. 7). Because cosmogenic exposure ages are minimum ages, the second option (Oldest Dryas) was favored for all the moraines dated in the upper part of the Grave valley and the Carlit plateau (Delmas et al., 2008). Here, the key question is rather: what was the extent of the glacial advance that occurred during the Oldest Dryas, knowing that around 19-20 ka cal. BP, i.e. during GS-2b, the terminal positions of the glaciers in this massif were confined to the floors of the cirques? The question arises especially for the upper part of the Têt valley, where the buried peatbog of La Grave offers a reference site that puts into perspective the cosmogenic data acquired locally with the help of other dating methods. Delmas et al. (2008) considered that the Oldest Dryas glacier could not have covered the radiocarbon-dated peatbog because (in contrast, for example, with the Portalet peatbog setting in Spain: Gonzalès-Sampériz et al., 2006), the exposed stratigraphy of the fill sequence shows no sedimentological or mechanical evidence of overriding by ice (e.g. absence of till between the dated peat and the overlying lacustrine and fluvioglacial units, no obvious compaction of the peat, no erosional stratigraphic unconformity). On the basis of this field evidence, the terminal position of the Oldest Dryas glacier was located just upstream from the buried peatbog, at a site $\sim 2150 \mathrm{~m}$ where a frontal moraine has yielded two cosmogenic ages of $13.3 \pm 2.0 \mathrm{ka}$ and $11.9 \pm 1.9 \mathrm{ka}$. Another age at $12.7 \pm 1.4 \mathrm{ka}$, which was obtained on a lateral moraine generated during a glacial stade whose the terminal position is situated $3 \mathrm{~km}$ downstream from the Grave peatbog site, has been rejected as unreliable; dating at $13.5 \pm 2.0 \mathrm{ka}$ obtained on a polished bedrock step situated $5 \mathrm{~km}$ downstream from La Grave site was also deemed unreliable for the same reasons.

Another way of interpreting this dataset is to retain all the cosmogenic results irrespective of up- or down-valley inconsistencies and consider that the Oldest Dryas cooling event in the Têt valley generated a glacial readvance of sufficent magnitude to produce a valley glacier 5 to $8 \mathrm{~km}$ long. Moreover, several ages on polished bedrock steps located on the floors of glacial cirques indicate that the last cirque glaciers disappeared in this massif during the Bølling-Allerød interstadial. Finally, the Younger Dryas cooling event seems to have promoted the development of rock glaciers. A similar chronosequence of landforms has been reported for all the smaller glaciated catchments located further west. For the smallest among these (Malniu, Duran, Llosa, Arànser), the last glacial advance occurred during the Oldest Dryas and the definitive disappearance 
of the ice occurred at the time of the Bølling-Allerød interstadial (Pallas et al., 2010; Palacios et al., 2015a). In the Querol valley, a cosmogenic age of $16.2 \pm 1.8 \mathrm{ka}$ from the Porté bedrock step, and of $14.9 \pm 1.3 \mathrm{ka}$ from the Vinyole moraine, has indicated that the Oldest Dryas glacier was about $7 \mathrm{~km}$ long in the Orri valley. In this same area, an age of $11.8 \pm 0.6 \mathrm{ka}$ obtained for a moraine located on the cirque floor indicates the persistence of a cirque glacier in this part of the massif until the Younger Dryas (Pallàs et al., 2010).

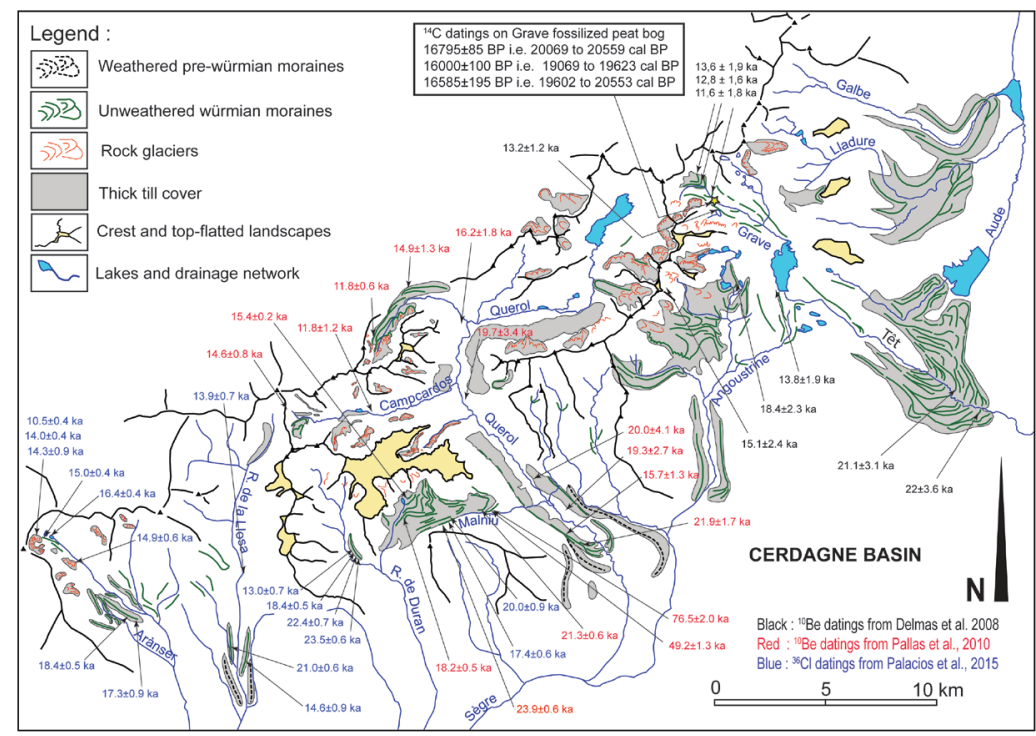

Figure 7. Glacial deposits and their associated ages on the south-easternmost side of the Pyrenees. After Delmas et al. (2008) and Palacios et al. (2015a).

In the Ariège glacial catchment, data on glacial fluctuations during the LGIT are currently limited to two sites (Fig. 3). In the main axis of the Ariège valley, the Petches moraines help to place the lateral ice margin of a $20 \mathrm{~km}$-long trunk glacier resulting from the confluence of three tributary glaciers in the catchment (En Beys, Nabre, and Mourguillou). All these glaciers originate from the north side of the Carlit massif and the easternmost margin of the Aston massif, which are the most elevated and most exposed to moist Atlantic air masses from the northwest. The Petches moraines are positioned $25 \mathrm{~km}$ up-valley from the Global LGM moraines, which occur in the Tarascon basin. Cosmogenic exposure ages currently available for the Petches stadial were not obtained from boulders located on the Petches moraine, but instead from three polished bedrock steps situated at Ax-les-Thermes, which lay beneath the Petches glacier at the time. The ages $(13.9 \pm 2.1 \mathrm{ka}, 15.2 \pm 3.3 \mathrm{ka}$ and $14.0 \pm 0.8 \mathrm{ka})$ indicate when the Ariège glacier left the Ax-les-Thermes bedrock step and retreated to the higher parts of the valley. Based on these results, (i) the glacial advance responsible for the Petches moraines has been ascribed to the Oldest Dryas, and (ii) the recession of the ice to the upper part of the valley to the Bølling-Allerød interstade. 
A second site documents the LGIT glacial extent in the Ariège catchment. This site is located in the Suc valley, a tributary of the Vicdessos River descending from the south side of the Trois Seigneurs massif $(2199 \mathrm{~m})$. This site was selected in order to confront cosmogenic ages acquired from this site with existing ${ }^{14} \mathrm{C}$ ages, alongside mineralogical, sedimentological and stratigraphic analysis obtained from a core in the glaciolacustrine fill sequence of Freychinède (Jalut et al., 1982, cf. section 2.1 and Fig. 3). Three cosmogenic ages $(16.7 \pm 2.3 \mathrm{ka}, 14.4 \pm 1.1 \mathrm{ka}$, and $14.1 \pm 0.7 \mathrm{ka})$ were obtained from a polished bedrock step located at 1360-1380 m between the Suc glacial trough and the Freychinède basin. The age sequence indicates that (i) a 150 m-thick glacier occupied the Suc valley during the Oldest Dryas. The terminal position of the small glacier is not easy to locate because there is no frontal or lateral moraine preserved in the Suc valley. However, the thickness of the ice just in front of the dated bedrock step suggests that the terminal position of this Oldest Dryas glacier was about $950 \mathrm{~m}$. (ii) During the Bølling-Allerød interstade, this glacier gradually retreated until it became confined to the cirques located on the south side of the Trois Seigneurs massif, and soon disappeared definitively. Indeed, it is highly probable that the Younger Dryas cooling event did not promote a new glacial advance in this area. The analysis of leaf stomata from botanical remains collected in the Freychinède borehole allow the Younger Dryas treeline altitude to be estimated at about $1300 \mathrm{~m}$ (Reille and Andrieu, 1993), i.e. only 400 to $600 \mathrm{~m}$ below the altitude of the cirque floor on the south side of the Trois Seigneurs massif (2199 m). On that basis, and by reference to the current situation, the minimum estimation for the Younger Dryas ELA is about 2300-2500 m, i.e. clearly above the crest of the Trois Seigneurs massif.

Finally, a series of 26 in situ-produced cosmogenic ${ }^{36} \mathrm{Cl}$ ages was recently produced from quartz samples in the upper part of the Gállego catchment (Palacios et al., 2015b, Fig. 4). As in the other Pyrenean valleys, these data were collected from polished surfaces on bedrock steps and from boulders on moraines. The results have allowed the extent of the Oldest Dryas glacial advance to be outlined, and also the rate at which the glacier retreated during the Bølling-Allerød to be characterized. The Oldest Dryas ice extent can be positioned in the Caldarés valley by the Bolática moraine and, in the Aguas Limpias valley, by the Formigal moraine. The location of these two lateral moraines on the valleyside shows that the glaciers in these two valleys were not joined up at that time. They also show that the upper part of the Gállego valley, which is located just below the Portalet pass and does not reach $2300 \mathrm{~m}$, was already ice-free. No cosmogenic exposure ages have been obtained from the Formigal moraine due to a lack of exposed boulders. However, three ages $(14.6 \pm 2.3 \mathrm{ka}, 12.3 \pm 1.6 \mathrm{ka}$, and $11.7 \pm 1.7 \mathrm{ka})$ were acquired in the upper part of the Aguas Limpias valley $8.6 \mathrm{~km}, 2.6 \mathrm{~km}$ and $2.4 \mathrm{~km}$ from the cirque headwalls. The Bolática moraine yielded two ages at $16.5 \pm 1.8 \mathrm{ka}$ and $13.9 \pm 2.0 \mathrm{ka}$. Behind this moraine, three ages $(12.2 \pm 1.5 \mathrm{ka}, 12.8 \pm 1.4 \mathrm{ka}$, and 13.9 $\pm 1.8 \mathrm{ka}$ ), respectively located $7.3 \mathrm{~km}, 6 \mathrm{~km}$ and $3.075 \mathrm{~km}$ from the cirque headwalls, show that the rate of deglaciation in this valley was similar to that in the Aguas Limpias valley. Moreover, these ages on polished bedrock steps indicate the possible presence of residual glaciers on the cirque floors during the Younger Dryas. The ages acquired in the Piniecho and Catieras cirques support this interpretation. 


\section{Conclusions}

The extent and chronology of the Pyrenean glaciation have been the subject of a great number of studies since the 19th century, but the timing of the last deglaciation has only begun to be constrained using radiometric dating since the last 30 years. The position and age of the Würmian MIE have now been well established. The last Pyrenean MIE occurred during MIS 4, and the terminal position of the Würmian MIE glaciers remains poorly defined in areas where deposits have not been well preserved. By contrast, knowledge of glacial fluctuations that occurred after MIS 4 is still in its infancy. Existing data have nonetheless captured the behavior of the Pyrenean glaciers during MIS 3. The fluctuations of outlet-glacier ice margins are relatively well constrained, but the true extent of these changes has not yet been calibrated. We are beginning to discern an east-west gradient in Pyrenean ice extent during the Global LGM, but this remains to be confirmed because of significant knowledge gaps that still remain regarding ice boundaries in some valleys. Evidence about post-LGM deglaciation is also incomplete. Early, rapid and extensive deglaciation can be inferred and extrapolated from local studies, but it is not possible to know yet whether the event occurred throughout the Pyrenees, or whether it only occurred in the massifs under stronger Mediterranean climatic regimes in the east and south. Similar uncertainty concerns the response of Pyrenean glaciers to the sequence of abrupt global climatic changes during the LGIT. Studies currently available are still too scarce to allow a Pyrenean-scale synthesis. The challenge is not so much of a chronological nature because the main climatic changes that occurred in the Pyrenees are the similar to those recorded on a global scale. The Oldest Dryas drove a glacial advance of much lesser magnitude than either the Global LGM or MIS 4. During the Bølling-Allerød interstadial, the ice margins retreated substantially, and some glaciers even locally disappeared. The Younger Dryas cooling event generated either a readvance of the ice front or the development of rock glaciers. The future challenge will be to date the Pyrenean ice extent during the Oldest Dryas, the Bølling-Allerød, the Younger Dryas and the Holocene more precisely than possible until now. Given the transitional position of the Pyrenees between Atlantic and Mediterranean climatic influences, this mountain range forms an ideal laboratory for studying the variability of local responses to abrupt climatic changes during the LGIT. The spatial variability of the ice extent is an interesting proxy that usefully complements existing models provided by vegetation and other biomarkers. Providing greater resolution to the spatial ice extent during the LGIT is therefore probably one of the more important issues for future research on glaciation in the Pyrenees. The task will probably be laborious given the fragmentation of the trunk glaciers into increasingly smaller units as the icefield contracted. But the potential is there because deposits are well preserved and because we now dispose of dating methods well suited to this kind of research.

\section{Acknowledgements}

The author thanks David Palacios for his invitation to write this paper and the two anonymous reviewers for their helpful comments on the manuscript. Many thanks also to Yanni Gunnell for his careful reading and corrections of the English. 


\section{References}

Alimen, H. 1964. Le Quaternaire des Pyrénées de Bigorre. Mémoire du Service de la Carte Géologique, Paris, 394 pp.

Andrieu, V. 1987. Le paléoenvironnement du piémont nord-pyrénéen occidental de $27000 \mathrm{BP}$ au Postglaciaire : la séquence d'Estarrès (Pyrénées Atlantiques, France) dans le bassin glaciaire d'Arudy. Comptes-Rendus de l'Académie des Sciences Série II 304, 103-108.

Andrieu, V. 1991. Dynamique du paléoenvironnement de la vallée montagnarde de la Garonne (Pyrénées centrales, France) de la fin des temps glaciaires à l'actuel. Thèse de Doctorat de 3e cycle, Université de Toulouse-le-Mirail, $311 \mathrm{pp}$.

Andrieu, V., Hubschman, J., Jalut, G., Hérail, G. 1988. Chronologie de la déglaciation des Pyrénées françaises. Dynamique de sédimentation et contenu pollinique des paléolacs : application à l'interprétation du retrait glaciaire. Bulletin de l'Association Française pour l'Étude du Quaternaire 34/35, 55-67.

Bakalowicz, M., Sorriaux, P., Ford, D.C. 1984. Quaternary glacial events in the Pyrenees from U-series dating of speleothems in the Niaux-Lombrives-Sabart caves, Ariège, France. Norsk Geografisk Tidsskrift 38, 193-197.

Barrère, P. 1963. La période glaciaire dans l'Ouest des Pyrénées centrales franco-espagnoles. Bulletin de la Société Géologique de France 7, 516-526.

Barrère, P., Calvet, M., Courbouleix, S., Gil Peña, I., Martin Alfageme, S. 2009. Carte géologique du Quaternaire des Pyrénées à 1:400 000. BRGM/IGME.

Birkeland, P.W. 1968. Correlation of Quaternary stratigraphy of the Sierra Nevada with that of the Lake Lahontan area. In R.B. Morrison, H.E. Wright (eds.), Means of correlation of Quaternary successions. International Association of Quaternary Research, Proceedings, 7th Congress, U.S.A., 8, pp. 469-500.

Birkeland, P.W. 1999. Soils and geomorphology. Oxford University Press, 430 pp.

Blockley, S., Lane, C.S., Hardiman, M., Rasmussen, S.O., Seierstad, I.K., Steffensen, J.P., Svensson, A., Lotter, A.L., Turney, C.S.M., Bronk Ramsey, C. INTIMATE members 2012. Synchronisation of palaeoenvironmental records over the last 60,000 years, and an extended INTIMATE event stratigraphy to 48,000 b2k. Quaternary Science Reviews 36, 2-10.

Bordonau i Ibern, J. 1992. Els complexos glacio-lacustres relacionats amb el darrer cicle glacial als pirineus. Geoforma Ediciones, Logroño, $251 \mathrm{pp}$.

Bordonau, J., Vilaplana, J.M., Fontugne, M. 1993. The Glaciolacustrine complex of Llestui (Central Southern Pyrenees): A key-locality for the chronology of the last glacial cycle in the Pyrenees. Comptes-Rendus de l'Académie des Sciences Série II 316, 807-813.

Calvet, M. 1996. Morphogenèse d'une montagne méditerranéenne: Les Pyrénées Orientales. Thèse de Doctorat d'Etat, Document du BRGM n ${ }^{\circ}$ 255, BRGM ed., Orléans, 1177 pp.

Calvet, M. 1998. Los Complejos Fluvioglaciares de Cerdanya-Capcir (Pirineos Orientales) y sus Enseñanzas. In Gomez, A., Pérez, A. (eds.), Las Huellas Glaciares de las Montañas Españolas. Universidad de Santiago de Compostela, Santiago de Compostela, pp. 263-290.

Calvet, M., Delmas, M., Gunnell, Y., Braucher, R., Bourlès, D. 2011. Recent advances in research on Quaternary glaciations in the Pyrenees. In Ehlers, J., Gibbard, P.L., Hughes, P. (eds.), Quaternary Glaciations, Extent and Chronology, a closer look Part IV. Elsevier. Developments in Quaternary Science, 15, pp. 127-139.

Copons, R., Bordonau, J. 1996. El registro sedimentario del cuaternario reciente en el lago Redó d'Aigües Tortes (Pirineos centrales). In Grandal d'Anglade, A., Pagés Valcarlos J. (eds.) $I V^{\circ}$ Reunión de Geomorfologia, Sociedad Española de Geomorfologia O Castro, pp. 249-260.

de Vernal, A., Eynaud, F., Henry, M., Hillaire-Marcel, C., Londeix, L., Mangin, S., Matthiessen, J., Marret, F., Radi, T., Rochon, A., Solignac, S., Turon, J.L. 2005. Reconstruction of sea- 
surface conditions at middle to high latitudes of the Northern Hemisphere during the Last Glacial Maximum (LGM) based on dinoflagellate cyst assemblages. Quaternary Science Reviews 24, 897-924.

de Vernal, A., Rosell-Melé, A., Kucera, M., Hillaire-Marcel, C., Eynaud, F., Weinelt, M., Dokken, T., Kageyama, M. 2006. Comparing proxies for the reconstruction of LGM sea surface conditions in the North-Atlantic. Quaternary Science Reviews 25, 2820-2834.

Delmas, M. 2005. La déglaciation dans le massif du Carlit (Pyrénées orientales): approches géomorphologique et géochronologique nouvelles. Quaternaire 16, 45-55.

Delmas, M., Gunnell, Y., Braucher, R., Calvet, M., Bourlès, D. 2008. Exposure age chronology of the last glacial cycle in the eastern Pyrenees. Quaternary Research 69, 231-241.

Delmas, M., Calvet, M., Gunnell, Y., Braucher, R., Bourlès, D. 2011. Palaeogeography and ${ }^{10} \mathrm{Be}$ exposure-age chronology of Middle and Late Pleistocene glacier systems in the northern Pyrenees: implications for reconstructing regional palaeoclimates. Palaeogeography, Palaeoclimatology, Palaeoecology 305, 109-122.

Delmas, M., Calvet, M., Gunnell, Y., Braucher, R., Bourlès, D. 2012. Les glaciations quaternaires dans les Pyrénées ariégeoises: approche historiographique, données paléogéographiques et chronologiques nouvelles. Quaternaire 23, 61-85.

Denton, G.H., Anderson, R.F., Toggweiler, J.R., Edwards R.L., Schaefer, J.M., Putnam, A.E. 2010. The Last Glacial Termination. Science 328, 1652-1656.

Depéret, C. 1923. Les glaciations des vallées pyrénéennes françaises et leurs relations avec les terrasses fluviales. Comptes Rendus Hebdomadaires des Séances de l'Académie des Sciences 176, 1519-1524.

Eberl, B. 1930. Die Eiszeitenfolge im nördlichen Alpenvorland. Augsbur, Benno Filser Verlag.

Emiliani, C. 1954. Temperature of Pacific bottom waters and polar superficial waters during the Tertiary. Science 119, 853-855.

Faucher, D. 1937. Le glacier de l'Ariège dans la basse vallée montagnarde. Revue Géographique des Pyrénées et du Sud-Ouest 8, 335-349.

Fontboté, J.M. 1948. La Ribera de Biescas. Pirineos 7, 39-88.

García-Ruiz, J.M., Valero-Garcés, B.L., Martí-Bono, C., González-Sampériz, P. 2003. Asynchroneity of maximum glacier advances in the central Spanish Pyrenees. Journal of Quaternary Science 18, 61-72.

García-Ruiz, J.M., Martí-Bono, C., Peña-Monné, J.L., Sancho, C., Rhodes, E.J., Valero-Garcés, B., González-Sampériz, P., Moreno, A. 2013. Glacial and fluvial deposits in the Aragón Valley, central-western Pyrenees: Chronology of the Pyrenean Late Pleistocene glaciers. Geografiska Annaler, Series A, Physical Geography 95, 15-32.

González-Sampériz, P., Valero-Garcès, B.L., Moreno, A., Jalut, G., García-Ruiz, J.M., MartíBono, C., Delgado-Huertas, A., Navas, A., Otto, T., Dedoubat, J.J. 2006. Climate variability in the Spanish Pyrenees during the last 30,000 yr revealed by the El Portalet sequence. Quaternary Research 66, 38-52.

Goron, L. 1941. Les vallums morainiques et les terrasses des dernières glaciations dans la région pré-pyrénéenne et son avant-Pays. Revue Géographique des Pyrénées et du Sud-Ouest 12, 5-429.

Hayes, A., Kucera, M., Kallel, N., Sbaffi, L., Rohling, E.J. 2005. Glacial Mediterranean sea surface temperatures based on planktonic foraminiferal assemblages. Quaternary Science Reviews 24, 999-1016.

Hétu, B., Gangloff, P. 1989. Dépôts glaciaires du Pléistocène inférieur sur le piémont des Pyrénées Atlantiques. Zeitschrift für Geomorphologie 33, 384-403.

Hoek, W.Z. 2009. The Last Glacial-Interglacial Transition. Episodes 31, 226-229. 
Hubschman, J. 1973. Etablissement par l'étude des faciès d'altération, d'un schéma stratigraphique du Quaternaire garonnais et ariégeois. Compte Rendu de l'Académie des Sciences Série D 277, 753-755.

Hubschman, J. 1975a. Les terrasses récentes de la Garonne et leur évolution. Bulletin de l'Association Française pour l'Etude du Quaternaire 12, 137-147.

Hubschman, J. 1975b. L'évolution des nappes alluviales antérissiennes de la Garonne dans l'avantpays molassique. Bulletin de l'Association Française pour l'Etude du Quaternaire 12, 149169.

Hubschman, J. 1975c. Morphogenèse et pédogenèse quaternaire dans le piémont des Pyrénées garonnaises et ariégeoises. Thèse de Doctorat d'Etat Lettres, Université de Toulouse leMirail (1974). Atelier de reproduction des Thèses de Lille III, 745 pp.

Hubschman, J. 1984. Glaciaire ancien et glaciaire récent: analyse comparée de l'altération de moraines terminales nord-pyrénéennes. In Montagnes et Piémonts, Hommage à François Taillefer. Revue Géographique des Pyrénées et du Sud-Ouest, Toulouse, 313-332.

Icole, M. 1973. Géochimie des altérations dans les nappes d'alluvions du piémont occidental nord-pyrénéen. Essai de paléopédologie quaternaire. Thèses sciences Paris, 328 pp.

Jalut, G., Delibrias, G., Dagnac, J., Mardones, M., Bouhours, M. 1982. A palaeoecological approach to the last 21000 years in the Pyrenees: The peat bog of Freychinède (Alt. $1350 \mathrm{~m}$, Ariège, South France). Palaeogeography, Palaeoclimatology, Palaeoecology 40, 321-359.

Jalut, G., Andrieu, V., Delibrias, G., Fontugne, M., Pagès, P. 1988. Palaeoenvironment of the valley of Ossau (Western French Pyrenees) during the last 27,000 years. Pollens et Spores 30, 357-394.

Jalut, G., Montserrat, J., Fontugne, M., Delibrias, G., Vilaplana, J.M., Julia, R., 1992. Glacial to interglacial vegetation changes in the northern and southern Pyrenees: deglaciation, vegetation cover and chronology. Quaternary Science Reviews 11, 449-480.

Llopis-Lladó, N. 1947. El relieve del Alto Aragón. Pirineos 5, 81-166.

Lewis, C.J., McDonald, E.V., Sancho, C., Peña, J.L., Rhodes, E.J. 2009. Climatic implications of correlated Upper Pleistocene and fluvial deposits on the Cinca and Gállego Rivers (NE Spain) based on OSL dating an soil stratigraphy. Global and Planetary Change 67, 141-152.

Lowe, J.J., Rasmussen, S.O., Björck, S., Hoek, W.Z., Steffensen, J.P., Walker, M.J.C., Yu, Z., INTIMATE group. 2008. Precise dating and correlation of events in the North Atlantic region during the Last Termination: a revised protocol recommended by the INTIMATE group: Quaternary Science Reviews 27, 6-17.

Mangerud, J., Andersen, S.T., Berglund, B.E., Donner, J.J. 1974. Quaternary stratigraphy of Norden, a propsal for terminology and classification. Boreas 3, 109-128.

Mardonnes, M., Jalut, G. 1983. La tourbière de Biscaye (alt. 409 m, Hautes Pyrénées): approche paléoécologique des 45000 dernières années. Pollen et Spores 25, 163-211.

MARGO Project Members, 2009. Constraints on the magnitude and patterns of ocean cooling at the Last Glacial Maximum. Nature Geoscience 2, 127-132.

Mengaud, M. 1910. Contribution à l'étude du glaciaire et des terrasses de l'Ariège et du Salat. Bulletin de la Société d'Histoire Naturelle de Toulouse 43, 19-41.

Nishiizumi, K., Imamura, M., Caffee, M., Southon, J., Finkel, R., McAnich, J. 2007. Absolute calibration of Be-10 AMS standards. Nuclear Instruments and Methods in Physics Research B 258, 403-413.

Palacios, D., Gómez-Ortiz, A., de Andrés, N., Vázquez-Selem, L., Salvador-Franch, F., Oliva, M. 2015a. Maximum Extent of Late Pleistocene Glaciers and Last Deglaciation of La Cerdanya Mountains, Southeastern Pyrenees. Geomorphology, 231, 116-129. 
Palacios, D., de Andrés, N., López-Moreno, J.I., García-Ruiz, J.M. 2015b. Late Pleistocene deglaciation in the central Pyrenees: the upper Gállego valley. Quaternary Research. doi:10.1016/j.yqres.2015.01.010.

Pallàs, R., Rodes, A., Braucher, R., Bourles, D., Delmas, M., Calvet, M., Gunnell, Y. 2010. Small, isolated glacial catchments as priority target for cosmogenic surface dating of Pleistocene climate fluctuations, SE Pyrenees. Geology 38, 891-894.

Pallàs, R., Rodés, A., Braucher, R., Carcaillet, J., Ortuno, M., Bordonau, J., Bourlès, D., Vilaplana, J.M., Masana, E., Santanach, P. 2006. Late Pleistocene and Holocene glaciation in the Pyrenees: a critical review and new evidence from ${ }^{10} \mathrm{Be}$ exposure ages, south-central Pyrenees. Quaternary Science Reviews 25, 2937-1963.

Panzer, W. 1926. Talentwicklung und Eiszeitklima im nordostlichen Spanien. Abhandlungen der Seckenbergischen Naturforschenden Gesellschaft 33, 1-155.

Peña, J.L., Sancho, C., Lewis, C., McDonald, E. Rhodes, E. 2004. Datos cronológicos de las morrenas terminales del glaciar del Gállego y su relación con las terrazas fluvioglaciares (Pirineo de Huesca). In J.L. Peña, L.A. Longares, M. Sánchez (eds.), Geografía Física de Aragón. Aspectos generales y temáticos, Universidad de Zaragoza e Institución Fernando El Católico, Zaragoza. pp. 71-84.

Penck, A. 1883. La période glaciaire dans les Pyrénées. Bulletin de la Société d'histoire naturelle de Toulouse 19, 105-200.

Penck, A. 1894. Studien über das Klima Spaniens während der Jüngeren Tertiärperiode und der Diluvialperiode. Zeitschrift Der Gesellschaft fur Erdkunde zu Berlin 29, 109-141.

Penck, A., Brückner, E. 1909. Die Alpen im eiszeitalter. Chr. Herm Tauchnitz, Leipzig, 1199 pp.

Planas, X., Corominas, J., Vilaplana, J.M., Altimir, J., Torrebadella, J., Amigó, J. 2011. Noves aportacions al coneixement del gran moviment del Forn de Canillo, Principat d'Andorra, Resúmenes XIII Reunió Nacional de Cuaternario, AEQUA, Andorra, pp. 163-167.

Putkonen, J., O'Neal, M. 2006. Degradation of unconsolidated Quaternary landforms in the western North America. Geomorphology 75, 408-419.

Putkonen, J., Connolly, J., Orloff, T. 2008. Landscape evolution degrades the geologic signature of past glaciations. Geomorphology 97, 208-217.

Rasmussen, S.O., Andersen, K.K., Svensson, A.M., Steffensen, J.-P., Vinther, B., Clausen, H. B., Siggaard-Andersen, M.L., Johnsen, S.J., Larsen, L.B., Dahl-Jensen, D., Bigler, M., Röthlisberger, R., Fischer, H., Goto-Azuma, K., Hansson, M., Ruth, U. 2006. A new Greenland ice core chronology for the last glacial termination. Journal of Geophysical Research 111, D06102, doi:10.1029/2005JD006079.

Rasmussen, S.O., Bigler, M., Blockley, S.P., Blunier, T., Buchar, S.L., Clausen, H.B., Cvijanovic, I., Dahl-Jensen, D., Johnsen, S.J., Fischer, H., Gkinis, V., Guillevic, M., Hoek, W.Z., Lowe, J., Pedro, J.B., Popp, T., Seierstad, I.K., Steffensen, J.P., Stevensson, A.P., Vallelonga, P., Vinther, B.M., Walker, M.J.C., Wheatley, J.J., Winstrup, M. 2014. A stratigraphic framework for abrupt climate changes during the last glacial period based on three syncromized Greemland ice-core records: refining and extending the INTIMATE event stratigraphy. Quaternary Science Reviews 106, 14-28.

Reille, M., Andrieu, V. 1993. Variations de la limite supérieure des forêts dans les Pyrénées (France) pendant le Tardiglaciaire. Compte Rendu de l'Académie des Sciences de Paris Série II 316, 547-551.

Reille, M., Andrieu, V. 1995. The late Pleistocene and Holocene in the Lourdes Basin, Western Pyrenees, France: new pollen analytical and chronology data. Vegetation History and Archaeobotany 4, 1-21.

Reimer, P.J., Bard, E., Bayliss, A., Beck, W.J., Blackwell, P.G., Bronk Ramsey, C., Buck, C.E., Cheng, H., Edwards, R.L., Friedrich, M., Grootes, P.M., Guilderson, T.P., Haflidason, H., 
Hajdas, I., Hatté, C., Heaton, T.J., Hoffmann, D.L., Hogg, A.G., Hughen, K.A., Kaiser, K.F., Kromer, B., Manning, S.W., Niu, M., Reimer, R.W., Richards, D.A., Scott, E.M., Southon, J.R., Staff, R.A., Turney, C.S.M., van der Plicht, J. 2013. Intcal13 and marine13 radiocarbon age calibration curves 0-50,000 years cal BP. Radiocarbon 55, 1869-1887.

Rodés Bolumburu, A. 2008. La última deglaciación en los Pirineos : Datación de superficies de exposición mediante ${ }^{10} \mathrm{Be}$, y modelado numérico de paleoglaciares. Thèse de Doctorat, Université de Barcelone, 238 pp.

Sancho, C., Peña, J.L., Lewis, C., McDonald, E., Rhodes, E. 2003. Preliminary dating of glacial and fluvial deposits in the Cinca River Valley (NE Spain): chronological evidences for the Glacial Maximum in the Pyrenees? In M.B. Ruiz Zapata, M. Dorado-Valiño, A. Valdeolmillos, M.J. Gil-García, T. Bardají, I. Bustamante, I. Mendizánal (eds.) Quaternary climatic changes and environmental crises in the Mediterranean region. Universidad de Alcalá de Henares, 169-173.

Sancho, C., Peña, J.L., Lewis, C., McDonald, E., Rhodes, E. 2004. Registros fluviales y glaciares cuaternarios en las cuencas de los ríos Cinca y Gállego (Pirineos y depresión del Ebro). In F. Colombo Piñol, C.L. Liesa Carrera, G. Meléndez Hevia, A. Pocoví Juan, C. Sancho Marcén, A.R. Soria de Miguel (eds.), Geo-Guías 11 Itinerarios Geológicos por Aragón, 181-216.

Sorriaux, P. 1981. Étude et datation de remplissages karstiques : nouvelles données sur la paléogéographie quaternaire de la région de Tarascon (Pyrénées ariégeoises). Comptes Rendus de l'Académie des Sciences Série II 293, 703-706.

Sorriaux, P. 1982. Contribution à l'étude de la sédimentation en milieu karstique. Le système de Niaux-Lombrives-Sabart (Pyrénées Ariégeoises). PhD thesis (unpubl.), Université Toulouse 3, Toulouse, $255 \mathrm{pp}$.

Svensson, A., Andersen, K.K., Bigler, M., Clausen, H.B., Dahl-Jensen, D., Davies, S.M., Johnsen, S.J., Muscheler, R., Parrenin, F., Rasmussen, S.O., Röthlisberger, R., Seierstad, I., Steffensen, J.P., Vinther, M.B. 2008. A 60,000 year Greenland stratigraphic ice core chronology. Climate of the Past 4, 47-57.

Taillefer, F. 1951. Le piémont des Pyrénées françaises. Privat, Toulouse, 383 pp.

Taillefer, F. 1960. Les terrasses d'obturation glaciaire de la vallée de Saurat (Ariège). Revue Géographique des Pyrénées et du Sud-Ouest 31, 45-61.

Taillefer, F. 1961. Recherches Récentes sur le Relief Glaciaire de la Vallée de l'Ariège. Pays de l'Ariège: Archéologie, Histoire, Géographie. Acte du Congrès d'études Régionales. Fédération des Sociétés Académiques et Savantes Languedoc-Pyrénées-Gascogne. F. Cocharaux, pp. 211-224.

Taillefer, F. 1963. La carte de Morphologie glaciaire des Pyrénées au 1/50 000. Feuilles de Foix et de Vicdessos. Revue Géographique des Pyrénées et du Sud-Ouest 34, 5-10.

Taillefer, F. 1967. Le Néoglaciaire Pyrénéen. In Mélange offerts à O. Tulippe, Deculot \& Gembloux, 134-147.

Taillefer, F. 1969. Les glaciations des Pyrénées. In: Actes VIII ${ }^{\circ}$ congrès international INQUA, Supplément au Bulletin de l'Association Française pour l'Etude du Quaternaire, Paris, pp. 19-32.

Taillefer, F. 1985. Idées actuelles sur les glaciations dans les Pyrénées de l'Ariège. Revue Géographique des Pyrénées et du Sud-Ouest 56, 323-338.

Turner, C., Hannon, G.E. 1988. Vegetational evidence for the late Quaternary climate changes in southwest Europe in relation to the influence of the North Atlantic Ocean. Philosophical Transactions of the Royal Society of London B318, 451-485.

Turu i Michels, V. 2002. Analisis secuencial del delta de Erts. Estratigrafia de un valle glaciar obturado intermitentemente. Relacion con el último ciclo glaciar. Valle de Arinsal, Pirineos Orientales. In Estudios recientes (2000-2002) en geomorfologia, patrimonio, montaña 
y dinamica territorial, SEG y Departamento de geografia, Universidad de Valladolid, Valladolid, pp. 555-574.

Turu i Michels, V., Peña Monné, J.L., 2006. Las terrazas fluviales del sistema Segre-Valira (Andorra-La Seu d'Urgell-Organyà, Pirineos Orientales): relación con el glaciarismo y la tectónica activa. In Pérez-Alberti, A., López-Bedoya, J. (eds.), Geomorfología y Territorio, IX Reunión Nacional de Geomorfología. Universidad de Santiago de Compostela, Santiago de Compostela, pp. 113-128.

Viers, G. 1960. Le relief des Pyrénées occidentales et leur piémont. Pays Basque français et Barétous. Thèse de Doctorat d'Etat Lettres, Privat, Toulouse, 604 pp.

Viers, G. 1961. Le glaciaire du massif du Carlit (Pyrénées-Orientales) et ses enseignements. Revue Géographique des Pyrénées et du Sud-Ouest 32, 5-33.

Viers, G. 1962. Les Pyrénées. Coll. Qué sais-je ? n 995, PUF, Paris, 128 pp.

Viers, G. 1963. Les moraines externes de la Cerdagne et du Capcir (Pyrénées orientales, France) et leurs rapports avec les terrasses alluviales. In VI ${ }^{\circ}$ Congrès INQUA, Varsovie 1961, vol. III, pp. 385-393.

Viers, G. 1968. La carte du relief glaciaire des Pyrénées. Feuille Mont-Louis au 1/50 000. Revue Géographique des Pyrénées et du Sud-Ouest 39, 429-434.

Vilaplana, J.M. 1983a. Quaternary Glacial Geology of Alta Ribagorça Basin (Central southern Pyrenees). Acta Geologica Hispanica 18, 217-233.

Vilaplana, J.M. 1983b. Estudi del glaciarisme quaternary de les altes valls de la Ribagorça. Unpublished PhD Thesis, Dept. de Geomorfologia i Tectònica, Facultad de Geologia, Universitat de Barcelona, 322 pp.

Vilaplana, J.M., Bordonau, J. 1989. Dynamique sédimentaire lacustre de marge glaciaire : le paléolac de Llestui (Noguera Ribagorçana, Versant sud des Pyrénées). Bulletin de l'Association Française pour l'Étude du Quaternaire 40, 219-224.

Wohlfarth, B. 1996. The chronology of the Last Termination: a review of radiocarbon-dated, high-resolution terrestrial stratigraphies. Quaternary Science Reviews 15, 267-284.

Zreda, M.G., Phillips F.M. 1994. Cosmogenic ${ }^{36} \mathrm{Cl}$ accumulation in unstable landforms. Water Resources Research 30, 3127-3136.

Zreda, M.G., Phillips, F.M. 1995. Insights into alpine moraine development from cosmogenic ${ }^{36} \mathrm{Cl}$ buildup dating. Geomorphology 14, 149-156. 